\title{
食物摄取資料分析方法に関する実証的研究
}

\author{
豊川裕 之*1, 西川浩昭*1, 城田知子*2 \\ 安武 律*3, 金子俊*4, 中島 順 一*5 \\ 永山育子*6

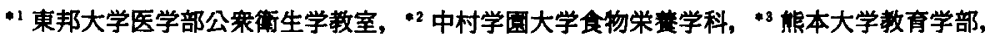

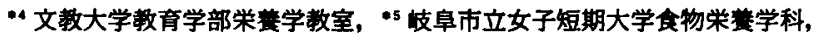 \\ “鳥取女子短期大学生活科学科
}

\section{An Original Method of Food Consumption Data Analysis}

Hiroyuki TOYOKAWA, "' Hiroaki NISHIKAWA,"1 Tomoko SHIROTA,*2 Ritsu YASUTAKE, ${ }^{* 3}$ Shun KANEKO,** Junichi NAKAJIMA*5 and Ikuko NAGAYAMA*6

"' Department of Public Health, Toho University School of Medicine, Oota-ku, Tokyo 143

-2 Department of Food and Nutrition Science, Nakamura Gakuen College, Fukuoka 814-01

*3 School of Education, Kumamoto University, Kumamoto 860

-4 Department of Nutrition Education, Bunkyo University, Koshigaya 343

*s Department of Food and Nutrition, Gifu City Women's College, Gifu 502

-6 Department of Life Science, Tottori Women's Junior College, Kurayoshi 682

Nippon Eiyō Shokuryō Gakkaishi (J. Jpn. Soc. Nutr. Food Sci.) 48, 253 270 (1995)

The authors have carried out food consumption surveys in small communities and statistical analysis related to both health evaluation and health improvement. In these studies, many types of indices and their definitions have suggested, i.e., food consumption structure, two-dimensional spatial diagram (for person/ food), food consumption pattern, mean standard deviation model, group cohesiveness, deviation pattern similarity, and acceptability of food articles. In this study the authors gauged the practical usefulness of these dietary indices using food consumption data for 159 female subjects who were surveyed by the authors twice, in 1979 and 1989, and who were living in 5 districts of Japan: Oami-Shirasato (Chiba Prefecture), Nakai (Kanagawa Pref.), Itadori (Gifu Pref.), Ajimu (Oita Pref.), and Tsunagi (Kumamoto Pref.). The results obtained were as follows : 1) During the 10-year study period, the amount of rice intake decreased in the rural districts of Itadori, Ajimu and Tsunagi, but did not decrease in the urban areas of Oami-Shirasato and Nakai, which are in Metropolitan Tokyo. It appeared that the rice consumption of the female population in metropolitan areas had already changed before 1979, while that in rural areas was just beginning to change during this period. 2) There were different levels of acceptability of food articles among the studied districts. Nevertheless, acceptability of rice continued to be constantly positive, whereas milk, the consumption of which had increased very much during this period, garnered only negative acceptability as a daily food; it was still seen as a favorite beverage, like juice or soda. 3) Food pattern plotted as a two-dimensional spatial diagram (for individual persons) was able to clearly delineate rural and metropolitan areas. Rural districts showed movement towards modern food patterns, while metropolitan districts showed movement towards easy/fast cooking patterns. 4) Deviation pattern similarity was able to show clearly chronological changes in the food intake patterns of each individual. It was evident that these patterns in the three rural districts

\footnotetext{
*1 $\overline{1} 143$ 東京都大田区大森西 5-21-16

$* 2$ 个 814-01 福岡市城南区別府 5-7-1

*3 $\% 860$ 熊本市黒髮 $2-40-1$

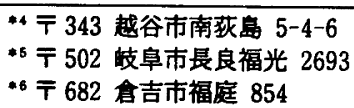


and those in Oami-Shirasato changed considerably, while the patterns for subjects in Nakai did not change, during the study period. The above results confirmed the usefulness of our food consumption analyses, and changing food patterns among Japanese women were clearly identified.

Key Words food consumption structure, two-dimensional spatial diagram, mean standard deviation model, group cohesiveness, deviation pattern similarity.

(Received September 29, 1994)

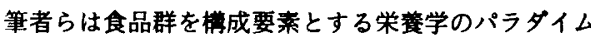
の設立に向けて研究してきた。そのための具体的方法論 として, 主として個人の食物捸取状況調查料を用いて, 多変量解析の手法によって分析してきた。その研究の進 捗にしたがっていくつかの新しい專門用語と統計量を提

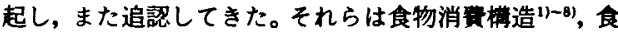

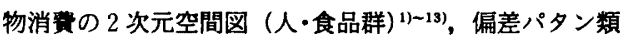
似率1415)などであり，その他にも平均-標準偏差模 型161 24) を用いて集団凝集力指数 ${ }^{71}$, 親和性指数 ${ }^{20) ~ 27) ~ な ~}$ どである。これらの一連の研究ては, 同時に, 他にも新 しい概念と指標をも提起することになった ${ }^{28) 29}$ 。そして, 食物消費構造は「相関係数行列」として国民栄程の現状 (厚生省)に，新しい統計資料として揭载されるように なった ${ }^{30)}$ 。

本報告では，同一対象を同一調査員が，10 年の間隔を おいて 2 度にわたって食物摄取状況調査を行って得た资 料を，上記の食物摂取状況に関する専門用語と統計量に よって, 両年次の食物捸取状況と地域的・経年的格差を 数量的に検討することを目的とする。

対 象

\section{1. 対象の選定}

2 年次・複数地区にわたる調查成續を収集するにあた り，対象（料）の条件として，(1)個人調查资料（世带 単位でなく)であること，(2) 秤量調査資料 (24 時間思い
出し法，その他科量を伴わない質問票調査資料を除く) であること, (3)地域の健常成人（病院, 職場, 学校の成 人ではなく)であること, (4) 本研究が 1989 年に実施され た関係で第 1 次調查が 10 年前の 1979 年に実施され，な おかつ(5) 調查者に起因する変動を除去するために各地 区は同一調査員によって調査できる対象であること，を 条件として対象を選定した。その結果,下記の 5 地区にま たがる女性 159 名が対象に選ばれた。

\section{2. 対象地区の跘明}

本研究の対象とした地区と対象は著者らが, 従来から フィールドとして栄荟と健康に関連したデータを収集 し，観察してきたところである。そのため，調査結果の フィードバックの際に若干の保健指䓕を行ったけれど も，とくに健康教育のプログラムを立てて実施すること はなかった地区ばかりである。それらの地区は，千葉県 山武郡大網白里町 (以下「大網」と略称), 神奈川県足柄 上郡中井町 (略称「中井」), 岐皁県武儀郡板取村 (略称 「板取」)，大分県宇佐郡安心院町 (略称「安心院」), 熊本 県芦北郡津奈木町（略称「津奈木」）の 5 力所である。対 象地区の概要（総面積，人口，年龄構成，人口増減）に ついて表 1 に示した。

大網は，西は千葉市に接しつつ，東は九十九里海岸を 形成する, 人口 30,000 人の町である。以前は農業と漁業 を中心としていたが，都心より約 90 分という便利さか ら，最近は通勤圈として急速に住宅地域化している。人

表 1. 対象地区の概要

\begin{tabular}{|c|c|c|c|c|c|c|c|c|}
\hline & \multirow{2}{*}{$\begin{array}{c}\text { 総面積 } \\
\left(\mathrm{km}^{2}\right)\end{array}$} & \multirow{2}{*}{$\begin{array}{c}\text { 国勢調查 } \\
\text { 人 口 } \\
\text { (人) }\end{array}$} & \multicolumn{5}{|c|}{ 年齢別人口粠成比（\%) } & \multirow{2}{*}{$\begin{array}{l}1985 \text { 年〜 } \\
1990 \text { 年の } \\
\text { 増減（\%)* }\end{array}$} \\
\hline & & & $\begin{array}{l}15 \text { 歳 } \\
\text { 末満 }\end{array}$ & $\begin{array}{l}15 \sim \\
29 \text { 歳 }\end{array}$ & $\begin{array}{l}30 \sim \\
44 \text { 歳 }\end{array}$ & $\begin{array}{l}45 \sim ~ \\
64 \text { 歳 }\end{array}$ & $\begin{array}{l}65 \text { 歳 } \\
\text { 以上 }\end{array}$ & \\
\hline $\begin{array}{c}\text { 千葉県山武郡 } \\
\text { 大網白里町 }\end{array}$ & 58.4 & 33,833 & 21.8 & 16.9 & 24.3 & 24.2 & 12.7 & 14.8 \\
\hline $\begin{array}{l}\text { 神奈川県足柄上郡 } \\
\text { 中井町 }\end{array}$ & 19.8 & 10,054 & 23.9 & 19.9 & 27.1 & 20.3 & 8.8 & 7.3 \\
\hline $\begin{array}{c}\text { 岐阜県武儀郡 } \\
\text { 板取村 }\end{array}$ & 185.8 & 2,089 & 16.1 & 15.6 & 15.8 & 32.7 & 19.8 & $\triangle 8.3$ \\
\hline $\begin{array}{c}\text { 大分県宇佐郡 } \\
\text { 安心院町 }\end{array}$ & 145.2 & 9,000 & 17.3 & 13.5 & 16.3 & 33.0 & 19.9 & $\triangle 6.2$ \\
\hline $\begin{array}{l}\text { 熊本県芦北郡 } \\
\text { 津奈木町 }\end{array}$ & 33.0 & 5,783 & 19.6 & 15.0 & 17.6 & 29.6 & 18.3 & $\triangle 3.9$ \\
\hline
\end{tabular}

* $\Delta$ は隇少，出典は 1990 年国勢調査結果。 
ロは,この 10 年間に 1.28 倍になっている。

中井は, 神奈川県の西部に位置する人口 10,000 人の町 でる。町内に鉄道の便はないが, 東名高速道路のイン ターチェンジがあり, 新宿副都心から 90 分程度といちこ とも加えて,ここ数年は首都通勤圈として発展している。 人口は, この 10 年間に 1.17 倍になっている。

板取(伎鼻県) は, 福井県との県境に位置し, 人口 2,000 人の典型的な山村てある。ここ数年は村役場としては キャンプ村としての開発を図っているが，その他には目 立った村おこしの成果は得られていない。人口は,この 10 年間で 0.91 倍に減じている。

安心院は, 大分県北部に位置し, 別府市, 湯布院町に 隣接した人口 10,000 人弱の町てある。鉄道の便はなく， 町へは別府市または中津市からのバスによる連絡に頼つ ている。なお, 近年アフリカン・サブァリが開設され, 畋光地となりつつある。人口は, この 10 年間て 0.92 倍に 減じている。

津奈木は, 熊本県の南西部に位置し, 南は水俣市に接 し八代海に面した人口 6,000 人の小さな農・漁業の町て ある。人口は, この 10 年間で 0.94 倍に減じている。

以上概述したことをまとめると，大網と中井の 2 地区 は大都市近郊地域であり,他の 3 地区は農山・漁村の町村 とみなすことができる。また, 都市近郊の 2 町では人口が 増加しているのに比へ, 他の 3 地区では人口の減少が生 じている。したがって,この 10 年間の都市近郊の 2 町は 他の晨山村 3 地区に比べて人口增だけではなく, 生活桭 境の変化が大きい。

\section{3. 対象者の年部命保成}

対象者 (女性) の地区別・年龄別權成は表 2 に示すとお りである。なお, 該当 10 年間に転出したものは除外され ており，重症の罹病経験者も含まれていない。大網で高 齢者が多いこと, 安心院で50 歳代が中心になっているこ となどの地域差があるが, 最年少は 32 歳, 最年長は 74 歳 (1989 年時点) である。

\section{調查方法と統計分析方法}

\section{1. 食物摄取状況の周查方法}

食物摄取状況調査方法は, 世帯単位ではなく, 個人単

表 2. 地区別 - 年難別対象数（1989 年時点）

\begin{tabular}{|c|c|c|c|c|c|c|}
\hline & $\begin{array}{c}\text { 千葉県 } \\
\text { 大網 } \\
\text { 白里町 }\end{array}$ & $\begin{array}{l}\text { 神奈 } \\
\text { 川県 } \\
\text { 中井町 }\end{array}$ & $\begin{array}{l}\text { 伎阜県 } \\
\text { 板取村 }\end{array}$ & $\begin{array}{c}\text { 大分県 } \\
\text { 安心 } \\
\text { 院町 }\end{array}$ & $\begin{array}{c}\text { 熊本県 } \\
\text { 津奈 } \\
\text { 木町 }\end{array}$ & 計 \\
\hline 50 歳末満 & 3 & 7 & 15 & 4 & 9 & 38 \\
\hline 50 歳代 & 9 & 6 & 13 & 22 & 11 & 61 \\
\hline 60 歳以上 & 21 & 7 & 15 & 7 & 10 & 60 \\
\hline 計 & 33 & 20 & 43 & 33 & 30 & 159 \\
\hline
\end{tabular}

位の調查であるという相違はあるが，厚生省国民栄黄調 查の食物掞取状況調查法に㸺じ，対象者本人が攝取した 食品を各自科量して，調査票に記録する自記式の秤量留 め零き法に加えて, 調查員が訪問して, 秤量と記載内容 をチェックするという訪問・面接聞き取りを重複した方 法である。

\section{2. 眮查時期}

調査の時期については各地区ごとに前後 2 回の調查が 同じ季節であるよう調整して,季節変勒要因は除去した。 全体として, 各地区とも 6〜10月の期間に実施された。

\section{3. テータの加エ}

集計は調查員自身が，調査した対象者の食物摄取状況 調查記録について 97 食品群（昭和 63 年度国民栄養調查 荷重食品成分表の分類に制じ）に分類して計算機に入力 し，栄秦素等撖取量の計算にはこれを用いたが，食品群 別摂取量については，さらに 23 の食品群(米, パン，め ん・その他, いも類, 砂糖, 菓子類, 油脂, 味㽞, 大豆・ 大豆製品, その他の豆類, 果実類, 緑黄色野菜, 淡色野 菜, 海藻類, 調味料, 酒類, 㫮好饮料, 魚介類, 肉類, タマコ, 乳, 乳製品, 加工食品)に丸めたものを用いた。

\section{4. 統計分析方法}

上述の手順で求められた食品群別捸取量 $(\mathrm{g} / 1$ 人 1 日) を変数として統計量を作成し，今までの代表値（平均摂 取量，標準偏差，充足率など）では説明できなかった食 物摂取状況を多角的に詳しく把握することができるよう に土夫した。

1）平均-標準偏差模型による親和性指数の算出 地 区別, 各調查年次別に平均值と標準偏差の対数をそれぞ れ横軸と縦軸にとり, 各食品群を平面上にプロットした

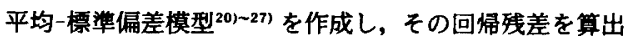
し,これを回㷌線当てはめにおける標洋誤差で除した商 を親和性指数 ${ }^{20)-27)}$ と呼んている。回㷌線は平均と標準 偏差の比例䦗係の最尤值を表しているから，図 1 ではあ る食品群（i）が平均値 $\left(x_{i}\right)$ を得たときの最尤的な標準 偏差が $\left(\mathfrak{y}_{i}\right)$ であることを示している。ところが, 標準偏 差の実測値が $y_{i}$ であると, 残差 $\left(y_{i}-y_{i}\right)>0$ であれば, $\hat{y}_{i}>y_{i}$ となる。つまり, 実測値のばらつき $\left(y_{i}\right)$ が最尤值 $\left(\mathfrak{y}_{i}\right)$ のばらつきより小さい。この条件が成り立つ食品群 (i)は,該集団の食物摄取状況のもとでは均一に消費され ていることになる(図1)。いま，ある食品群が均一に食 ベられることが不均一に食べられている食品群よりも該 集団に受け容れられ定着している一親和性がある一と考 えるならば, 食品群（i）は親和性が強いことになる（図 1)。なお, $\left(y_{i}-y_{i}\right) / s$ は, 二つ以上の集団の親和性指数を 比較するときに必要な標準化の操作である。

2）食物消費構造の表示と食物消費の 2 次元空間図 また, 各年次ごとの食品群間の相関関係を計算し，その 


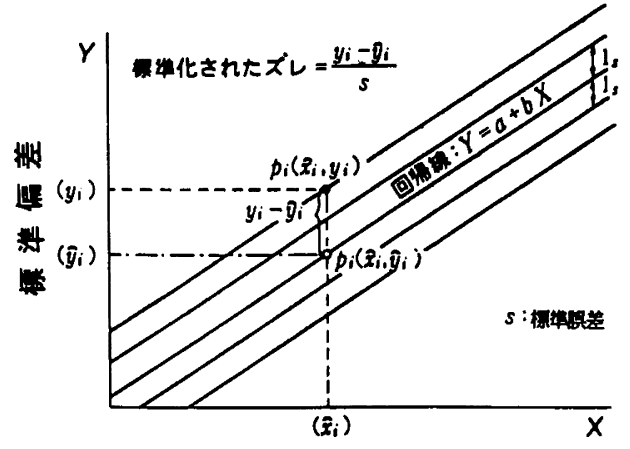

図 1. 回㛿線からのスレの標䇲化

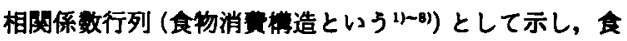
物消费の仕方に槽造があることを示した。さらにその橉 造を決定している因子を明らかにする目的て因子分析ゃ 主成分分析を行って食物摄取を決める要因（因子）を求 めることがてきる。その竦み取りを容易にするために「食 物消霓の 2 次元空間図 (食品群)」に図示する。さらに各 要因別に対象者個人の因子得点を算出して,「食物消费の
2 次元空間図 (人)」にプロットさせて個人の食物消費特

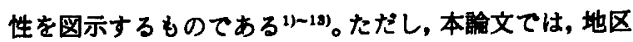
こととの食物消費特性を図示したので「食物消零の 2 次元 空間図（地区）」を用いた。

3）偏差パタン類似率の算出 また, 上記の多変至解 析とは別途に，対象者個人について下式によって，両調 查年次間の偏差パタン類似率 ${ }^{10115)}$ を算出し, 10 年間にわ たる変化を㭘証した。

$$
S_{i}=\frac{\Sigma\left(x_{1 k}-x_{1 k}\right)\left(x_{2 k}-x_{2 k}\right)}{\sqrt{\Sigma\left(x_{11 k}-x_{1 k}\right)^{2}} \sqrt{\Sigma\left(x_{21 k}-x_{2 k}\right)^{2}}}
$$

$S$ は偏差パタン類似率, $x$ は攝取量 $\mathrm{g} /$ day, 1,2 は調 查年次の第 1 次, 第 2 次, $i$ は对象者, $k$ は食品群。

結果

\section{1. 食品群別挎取且の变化}

1979 年と 1989 年の両年次の食品群別摄取量 (平均) を 表 3 に示した。この 10 年間, 全 5 地区で米, 味啪の摂取 量が減少しており, 大網，中井両地区（首都圈地域）を 除く 3 地区てパンの摂取量が增加していた。大網, 中井両 地区は 1979 年の時点で, 米摄取量がすでに少吾になって おり，この調査期の 10 年間の減少量は小幅であり(大網

表 3. 地区別・年次別の食品群別捸取量

\begin{tabular}{|c|c|c|c|c|c|c|c|c|c|c|}
\hline \multirow{3}{*}{$\begin{array}{l}\text { 対象地区 } \\
\text { 対象者数 } \\
\text { 調查年次 }\end{array}$} & \multicolumn{2}{|c|}{ 大網白里町 } & \multicolumn{2}{|c|}{ 中井町 } & \multicolumn{2}{|c|}{ 板取村 } & \multicolumn{2}{|c|}{ 安心院町 } & \multicolumn{2}{|c|}{ 津奈木町 } \\
\hline & \multicolumn{2}{|c|}{33} & \multicolumn{2}{|c|}{20} & \multicolumn{2}{|c|}{43} & \multicolumn{2}{|c|}{33} & \multicolumn{2}{|c|}{30} \\
\hline & 1979 年 & 1989 年 & 1979 年 & 1989 年 & 1979 年 & 1989 年 & 1979 年 & 1989 年 & 1979 年 & 1989 年 \\
\hline 米 & 210.7 & 181.5 & 156.9 & 136.8 & 322.7 & $188.0^{* *}$ & 285.4 & $185.6^{* *}$ & 241.1 & $168.5^{* *}$ \\
\hline パン & 22.0 & 18.9 & 40.2 & 36.0 & 10.9 & 14.6 & 6.4 & 19.3 & 9.1 & $14.5^{\circ}$ \\
\hline めん・その他 & 32.0 & 34.1 & 48.9 & 51.6 & 21.8 & 28.3 & 34.9 & 21.7 & 35.2 & 30.8 \\
\hline いも類 & 43.9 & $71.1^{* *}$ & 50.0 & 40.6 & 112.1 & $74.5^{* *}$ & 39.0 & 29.4 & 44.2 & 40.0 \\
\hline 砂唐 & 15.4 & 14.2 & 19.4 & $11.0^{*}$ & 13.9 & 13.0 & 8.7 & 9.8 & 8.4 & 10.6 \\
\hline 菓子類 & 65.2 & 56.0 & 23.4 & 26.2 & 12.8 & $25.0^{*}$ & 5.4 & 29.4 & 29.3 & $26.3^{* *}$ \\
\hline 油脂 & 20.5 & 14.1 & 24.9 & 20.0 & 11.1 & 9.6 & 9.5 & 10.1 & 9.7 & 13.3 \\
\hline 味婙 & 22.2 & $19.6^{\circ}$ & 16.4 & 13.7 & 25.3 & $14.1^{* *}$ & 26.1 & 19.7 & 25.0 & $20.0^{*}$ \\
\hline 大豆食品 & 71.5 & 58.6 & 61.3 & 79.6 & 61.8 & 53.0 & 39.7 & 57.0 & 55.5 & 74.6 \\
\hline その他の豆類 & 2.3 & $7.6^{*}$ & 2.4 & 3.4 & 6.8 & 2.3 & 0.1 & 2.3 & 1.1 & $0.7^{*}$ \\
\hline 果実類 & 171.4 & $229.0^{\circ}$ & 180.2 & 156.7 & 131.6 & 148.0 & 165.8 & 170.8 & 182.5 & 174.6 \\
\hline 緑黄色野莱 & 113.1 & 128.1 & 158.1 & 182.4 & 54.7 & 49.5 & 91.8 & 70.6 & 79.7 & 84.7 \\
\hline 淡色野莱 & 206.7 & 211.0 & 248.8 & 218.7 & 242.0 & $165.8^{* *}$ & 200.7 & 226.7 & 196.6 & 186.6 \\
\hline 海濐類 & 6.5 & $9.7^{*}$ & 6.8 & 10.9 & 3.6 & 2.8 & 8.8 & 6.6 & 4.7 & 3.6 \\
\hline 調味料 & 29.5 & 33.6 & 37.5 & 37.7 & 38.7 & $30.0^{* *}$ & 20.8 & 30.8 & 26.9 & $24.3^{* *}$ \\
\hline 酒類 & 27.2 & 29.9 & 52.4 & 22.5 & 4.2 & 13.2 & 0.3 & 8.7 & 31.2 & $45.3^{* *}$ \\
\hline 囎好飲料 & 41.2 & 31.7 & 75.9 & 145.9 & 5.9 & 23.0 & 3.0 & 57.8 & 18.9 & $48.1^{* *}$ \\
\hline 魚介類 & 99.6 & 123.1 & 92.5 & 90.5 & 62.7 & 71.4 & 59.2 & 88.7 & 121.0 & $96.2^{* *}$ \\
\hline 肉類 & 46.5 & 50.0 & 63.3 & 50.6 & 44.3 & 40.4 & 47.7 & $40.8^{*}$ & 51.9 & 36.5 \\
\hline 卵 & 48.1 & 53.7 & 39.1 & 42.5 & 30.7 & 39.6 & 34.1 & $35.6^{* *}$ & 25.7 & 42.1 \\
\hline 拜 & 63.0 & $128.8^{* *}$ & 130.9 & 103.6 & 25.4 & $68.3^{* *}$ & 11.4 & $145.0^{*}$ & 68.3 & $123.5^{* *}$ \\
\hline 㲕憋品 & 9.3 & 14.6 & 10.1 & 18.3 & 0.3 & $5.6^{*}$ & 2.0 & 5.3 & 1.1 & 19.8 \\
\hline 加工食品 & 23.9 & 27.2 & 20.8 & 21.1 & 12.3 & 16.5 & 8.1 & $8.3^{* *}$ & 3.7 & 12.4 \\
\hline
\end{tabular}

差の検定：" $p<0.01, " p<0.05$. 
Vol. 48 No. 41995

$210.7 \mathrm{~g} \rightarrow 181.5 \mathrm{~g}$, 中井 $156.9 \mathrm{~g} \rightarrow 136.8 \mathrm{~g}$ ), 他は大幅な 娍少(板取 $322.7 \mathrm{~g} \rightarrow 188.0 \mathrm{~g}$, 安心院 $285.4 \mathrm{~g} \rightarrow 185.6$ $\mathrm{g}$, 津奈木 $241.1 \mathrm{~g} \rightarrow 168.5 \mathrm{~g}$ )となっている。パン摄取量 も大網, 中井両地区だけは 10 年間に減少していた(大棢 $22.0 \mathrm{~g} \rightarrow 18.9 \mathrm{~g}$, 中井 $40.2 \mathrm{~g} \rightarrow 36.0 \mathrm{~g})$ 。酒は, 中井を除 く4地区て, また㖺好飲料は大網を除く 4 地区で增加し ているが，後述するようにこれらの地区の女性が飲酒ゃ 㖺好拎料に対する親和性を強めたわけてはなく, 少数の 女性が多量を飲むようになったために平均値が増加した のである。卵の摄取量は全地区で增加したが, 有意に增 加しているのは 2 地区だけてあった。秃については, 1979 年の時点ですてに $130.9 \mathrm{~g}$ に達していた中井地区 (130.9 $\mathrm{g} \rightarrow 103.6 \mathrm{~g})$ を除き,すべての地区てこの 10 年間に做增 しており，全体として捸取量が倍增している。

とくに米について 1979 年と 1989 年の各個人の掫取量 を散布図 (図2)に示した。図の横軸 $(X)$ は 1979 年次,
繸軸 $(Y)$ は 1989 年次の提取量を示している。また各地 区別に確率集中棈円を描き，棈円内に約 $65 \%$ が含まれる ようにした。全地区の棈円は点線 $(Y=X)$ より下方に 偏り，摄取量が減少していること $(Y<X)$ を示してい る。しかしその減少の度合いには, 地域差が認められ, 莀村地区である津奈木, 安心院, 板取で摄取量にして 80〜140（g）娍少し，率にして 1979 年次の $30.1 \%$ (最 小)〜 41.7\% (最大) に減少した。他方, 首都四に位置し ている大網と中井では, 減少幅が小さく，20３0（g） (12.8\% 13.9\%)程度の減少に留まったが, 1979 年次の 摄取量が $157 \mathrm{~g}$ てあった中井についてはこの程度の減少 に留まった。また，大網でも 1979 年次の掫取量が $210 \mathrm{~g}$ てあり，1989 年には $30(\mathrm{~g})$ 減少の $181.5 \mathrm{~g}$ に留まってお

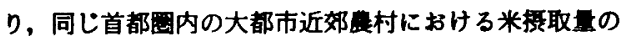
減少率は小さくなっている。同様に，米以外の食品群に ついて個々に比较すると管山・漁村地区と都市近郊地区

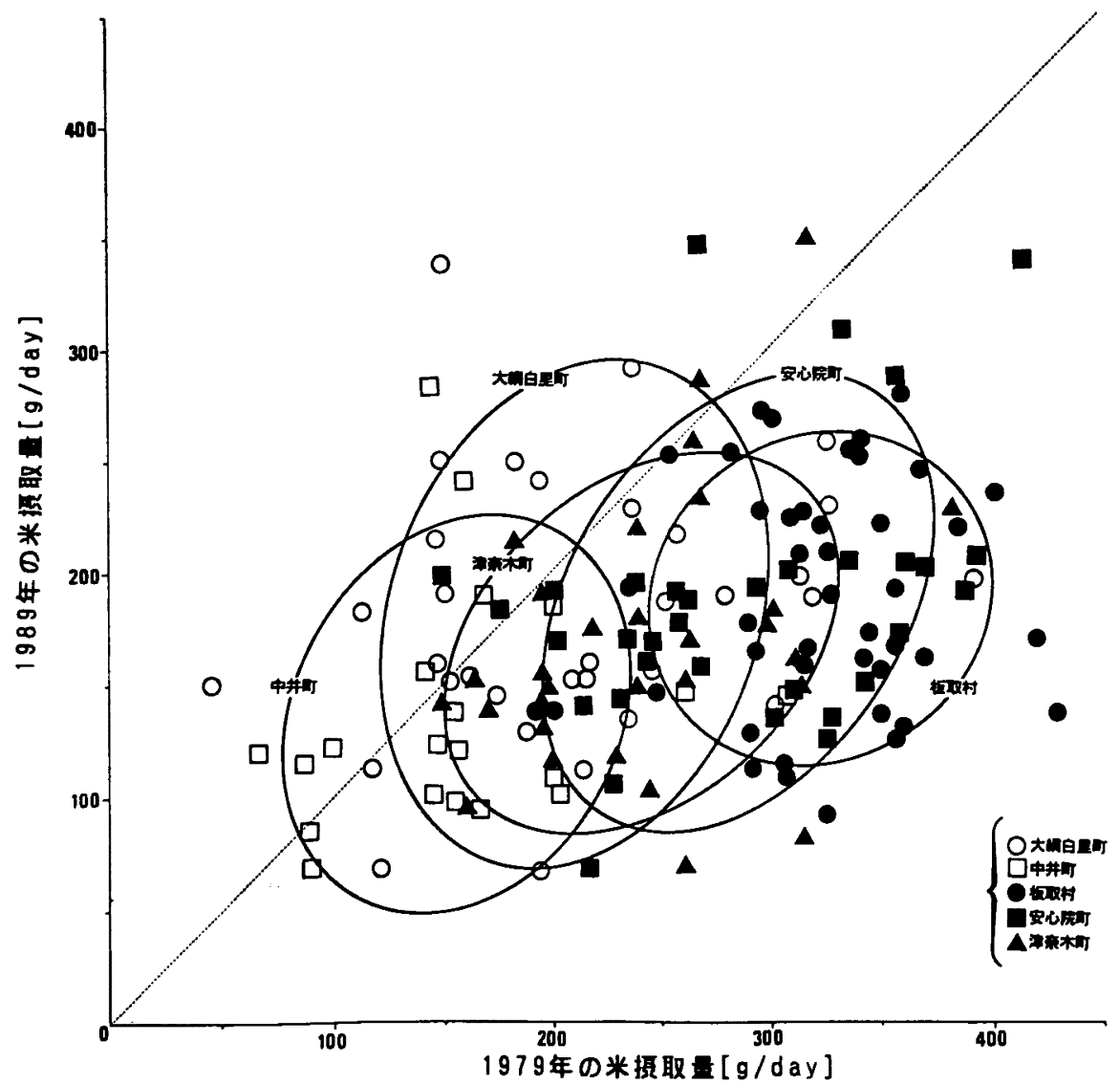

図 2. 米摄取量の年次変化 
における食生活の変化の相逗を見いだすことができる が, 同時に一筋網ては説明のつかない変化の多様性があ ることも否定てきない。それらについては，後述する他 の統計量（親和性指数や偏差パタン類似率など）によっ て，すへてではないが，かなり掘り下げた説明がなされ る。

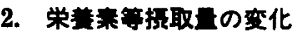

両調査年次における策荃素等摄取量を 97 食品群分類 に基づき四訂日本食品赀準成分表によって計算し表 4 に 示した。ただし，地区単位としての代表値のみを示すに 留める。エネルギー摄取量については全地区で減少した が，統計的に有意に娍少しているのは板取だけである。 栄蛽素については, まず脂買は板取, 安心院, 津奈木の 純㖘村地区て増加している。ただし，その中の板取だけ は統計的に有意てはない。次に粕質は全 5 地区で減少し ているが,純甞村地区ては統計的に有意に減少している。 他の栄意素については，首都圈地区，純鼎村地区の差は 見いだせない。また结村地区の中でも足並みが揃った変 化がない。首都圈内の大䑺と中井との間にも较差があり， 中井はほとんど変化がないけれども，大網はカルシウム とピタミン $\mathrm{B}_{2}$ が增え,ビタミン $\mathrm{A}$ が減少している。これ らの変化は, 食品標淖成分表によって計算した值なので, これ以上に㨄り下げることはしない。

\section{3. 親和性指数の変化}

両年次における地区別・食品群別親和性指数を表 5 に 示した。親和性指数の符号（十）は該当集団内でぱらつ
き（レンジ）が小さい状況の食べられ方をしており，と りもなおさず均一に食べられていることであるから、こ のような摄取状態を親和性が強いとすることができ

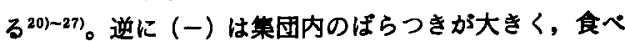
る人と食べは人の格差（レンジ）が大きいのて，これ を親和性が弱いとしている。そして数值は親和性の強弱 の度合いを示すものである 201 27)。米について親和性の強 弱をみると，両年次とも，すべての地区において親和性 指数は正の值であり，親和性が強く安定した食へられ方 をしている。しかし, 純莀村の板取, 安心院, 津奈木の 3 地区ては後述するように, 摄取量が大幅に減少し,かつ 親和性の強さが弱まっている。この変化は, 純鹿村地区 で，女性の米摄取专が一漛に減少したのではなく，な かには大幅に減らした人もいることによって，個人格差 が大きくなった。その結果, 米に対する親和性が弱くなっ たのであるか，それでも正の親和性を維持していること になる。親和性が正の数値て占められている食品群は, 米の他に油脂, 砂榶, 調味料, 肉, 卵である。魚介類は 1979 年次の中井と板取の両地区だけて負の親和性を示 したが，山村の板取では魚に対する親和性が他に比べて とくに弱い。他方, パンの親和性については, 1979 年の 中井を除き，すべての地区・年度て負であり，1989 年で はその中井でも負になり, 全地区で親和性が弱くなって いる。また乳については，すべての地区・両年次て負の 親和性指数であるが, 中井を除く他の 4 地区では, その度 合いが小さくなっている。酒類や㖺好飲料は乳より大き

表 4. 地区別・年次別の栄素素等摄取量

\begin{tabular}{|c|c|c|c|c|c|c|c|c|c|c|}
\hline \multirow{3}{*}{$\begin{array}{l}\text { 対象地区 } \\
\text { 対象者数 } \\
\text { 調查年次 }\end{array}$} & \multicolumn{2}{|c|}{ 大網白里町 } & \multicolumn{2}{|c|}{ 中井町 } & \multicolumn{2}{|c|}{ 板取村 } & \multicolumn{2}{|c|}{ 安心院町 } & \multicolumn{2}{|c|}{ 津奈木町 } \\
\hline & \multicolumn{2}{|c|}{33} & \multicolumn{2}{|c|}{20} & \multicolumn{2}{|c|}{43} & \multicolumn{2}{|c|}{33} & \multicolumn{2}{|c|}{30} \\
\hline & 1979 年 & 1989 年 & 1979 年 & 1989 年 & 1979 年 & 1989 年 & 1979 年 & 1989 年 & 1979 年 & 1989 年 \\
\hline $\begin{array}{c}\text { エネルギー } \\
\text { (kcal) }\end{array}$ & 2261 & 2182 & 2101 & 1942 & 2153 & $1717^{* *}$ & 1874 & 1778 & 1905 & 1800 \\
\hline タンパク䆩 (g) & 82.1 & 88.0 & 80.7 & 81.9 & 74.1 & $65.2^{*}$ & 62.2 & 70.3 & 76.6 & $69.9^{* *}$ \\
\hline 脂筫 $(\mathrm{g})$ & 64.7 & 58.1 & 64.1 & 57.2 & 40.3 & 41.2 & 35.5 & $44.5^{\circ}$ & 42.4 & $49.8^{* *}$ \\
\hline 耤䝷 (g) & 327.6 & 317.2 & 289.6 & 273.2 & 359.9 & $260.7^{* *}$ & 316.3 & $267.9^{*}$ & 292.2 & $256.7^{* *}$ \\
\hline $\begin{array}{c}\text { カルシウム } \\
\text { (mg) }\end{array}$ & 615 & $727^{*}$ & 677 & 726 & 505 & 475 & 345 & $582^{*}$ & 481 & $564 * *$ \\
\hline 鉄分 (mg) & 11.5 & 12.5 & 11.3 & 12.1 & 11.2 & $9.5^{* *}$ & 8.8 & 9.5 & 10.0 & $9.4^{*}$ \\
\hline $\begin{array}{c}\text { ピタミンA } \\
\text { (IU) }\end{array}$ & 2081 & $2699^{*}$ & 2196 & 2690 & 1720 & 1541 & 1560 & $1834^{*}$ & 1495 & 1803 \\
\hline $\begin{array}{l}\text { ビタミン } B_{1} \\
(\mathrm{mg})\end{array}$ & 1.3 & 1.4 & 1.4 & 1.3 & 1.2 & $1.0^{* *}$ & 1.0 & 0.9 & 1.1 & 1.0 \\
\hline $\begin{array}{l}\text { ピタミン } B_{2} \\
\text { (mg) }\end{array}$ & 1.2 & $1.5^{* *}$ & 1.4 & 1.4 & 1.0 & 1.0 & 0.9 & $1.2^{*}$ & 1.1 & $1.2^{*}$ \\
\hline $\begin{array}{c}\text { ピタミンC } \\
(\mathrm{mg})\end{array}$ & 168 & 178 & 186 & 174 & 146 & $125^{*}$ & 157 & 152 & 138 & 147 \\
\hline 食塩 (g) & 14.8 & 15.4 & 16.9 & 15.6 & 15.1 & $12.4^{* *}$ & 13.7 & 14.6 & 11.8 & 12.7 \\
\hline
\end{tabular}

差の検定 : "* $p<0.01, " p<0.05$. 


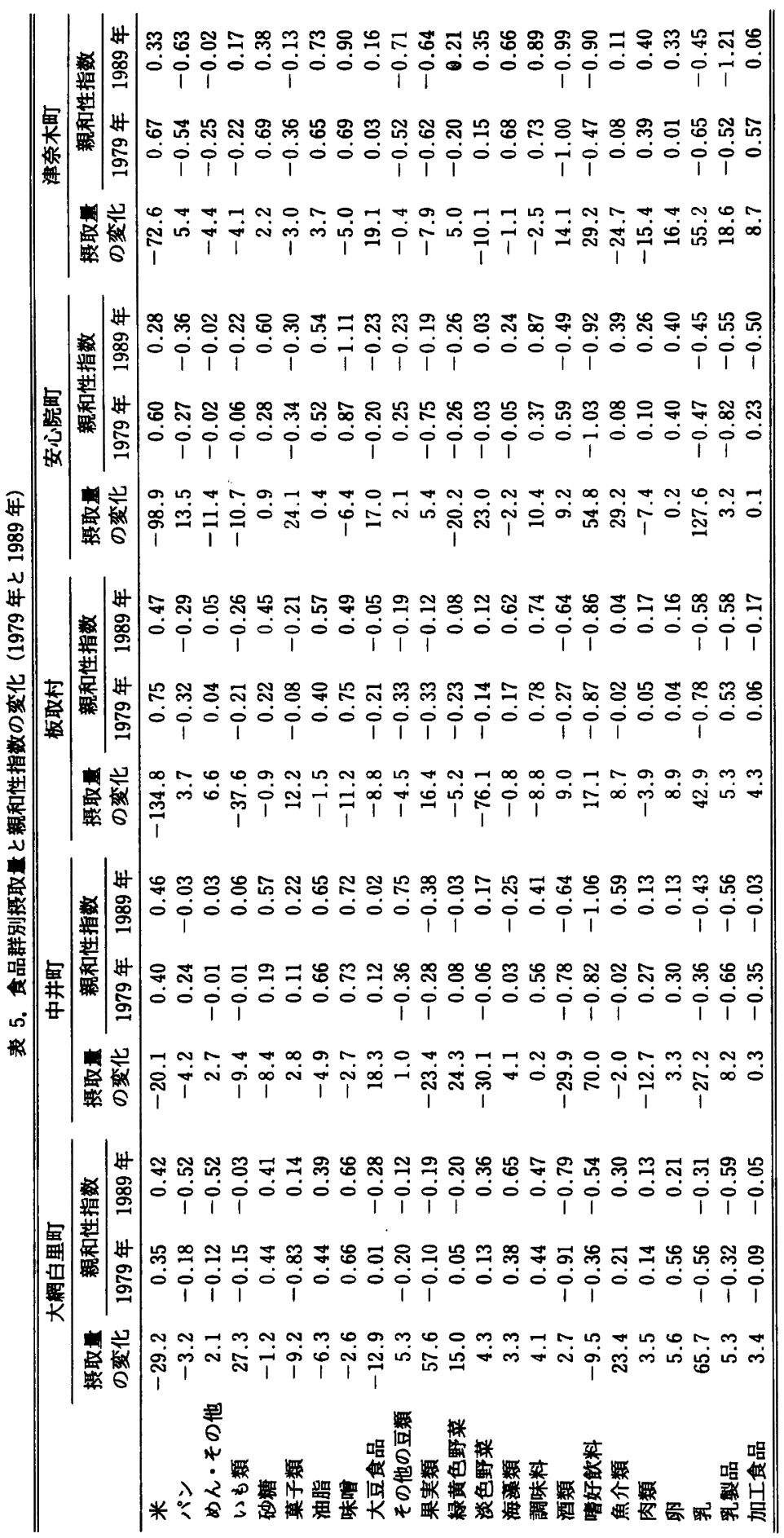


い負値の親和性を得ている。しかし乳は，肉，卵，油脂， 砂糖，調味料とは異貿の親和性を示し，酒，㖺好钦料に 類似の拱取のされ方をしている。それでもこの 10 年間 に乳は酒, 㖺好飲料加離れて肉, 卵, 油脂, 砂糖の摄 られ方に近づいてきていることがわかる。これらの結果 から, 日本人の女性ては乳が酒・㖺好飲料と同し㖺好品 として受け入れられていたが,ようやく副食品のような 提られ方をするようになったことがこの分析て明らかに
なった。

4. 平均技取目の变化と親和性指数の変化の合成 次に平均摄取量と親和性指数の共変動をみると，食物 摄取状況の変化について新しい側面がみえてくる。図 3 に各地区ごとの平均摄取量と親和性指数を変量とする各 地区, 各年次の状況とその変化を示した。横軸は平均挃 取量を示し，綎軸は親和性指数を示しており，矢印の向 きは時間的経過を示している。この図では，時間的経過

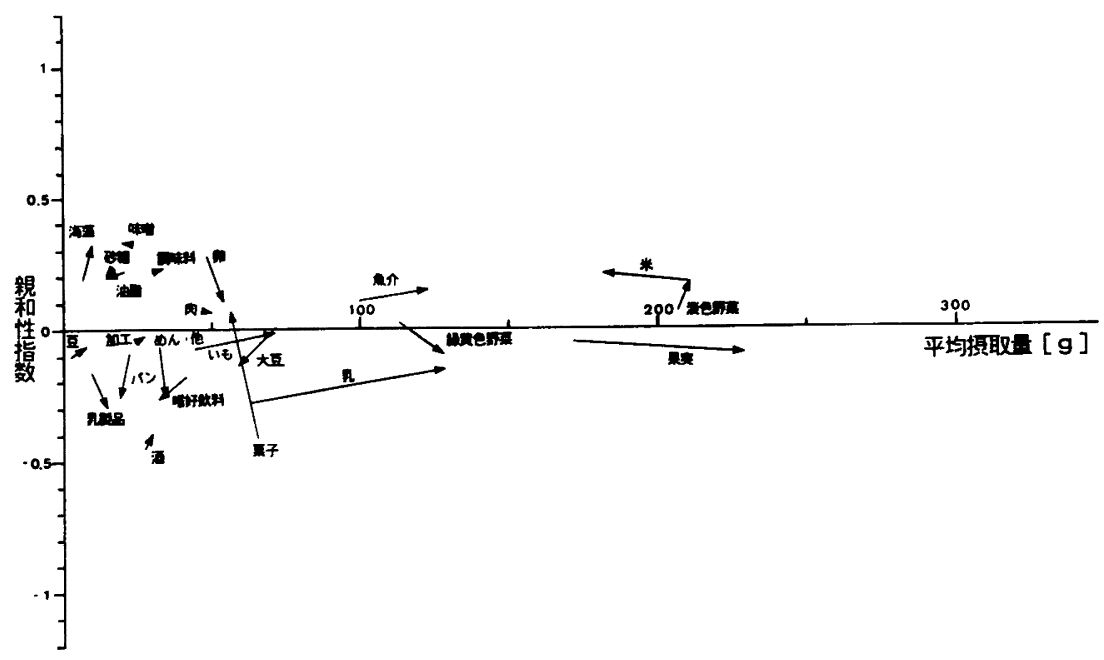

図 3-a. 平均提取量と親和性指数（1979 年と 1989 年, 大網白里町）

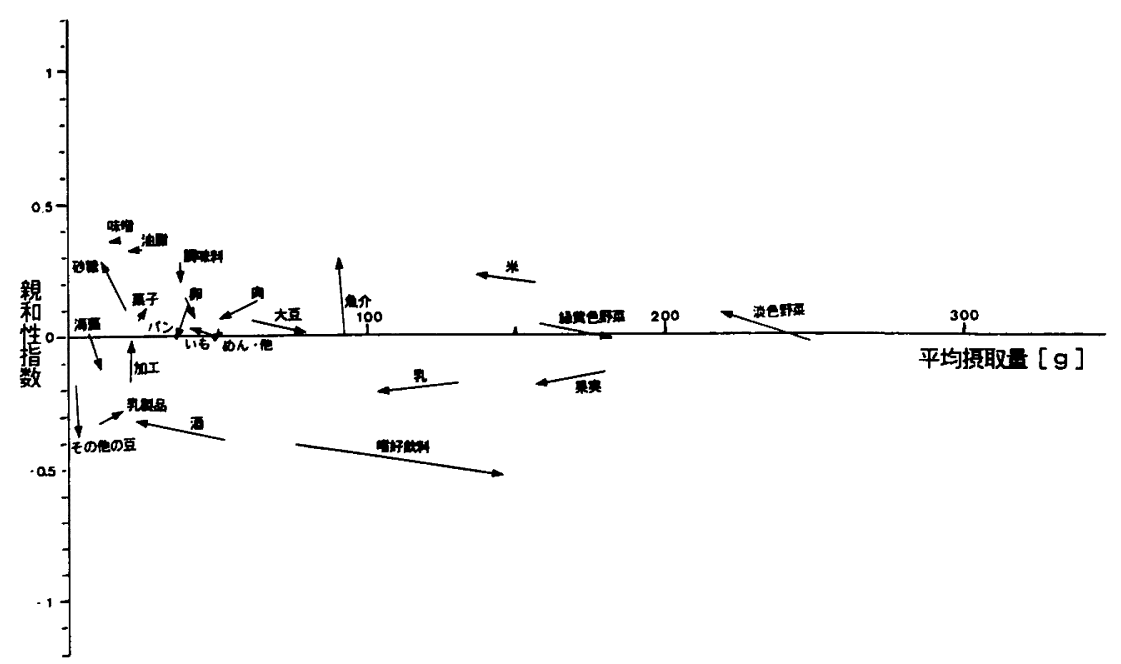

図 3-b. 平均搯取量と親和性指数（1979 年と 1989 年, 中井町) 


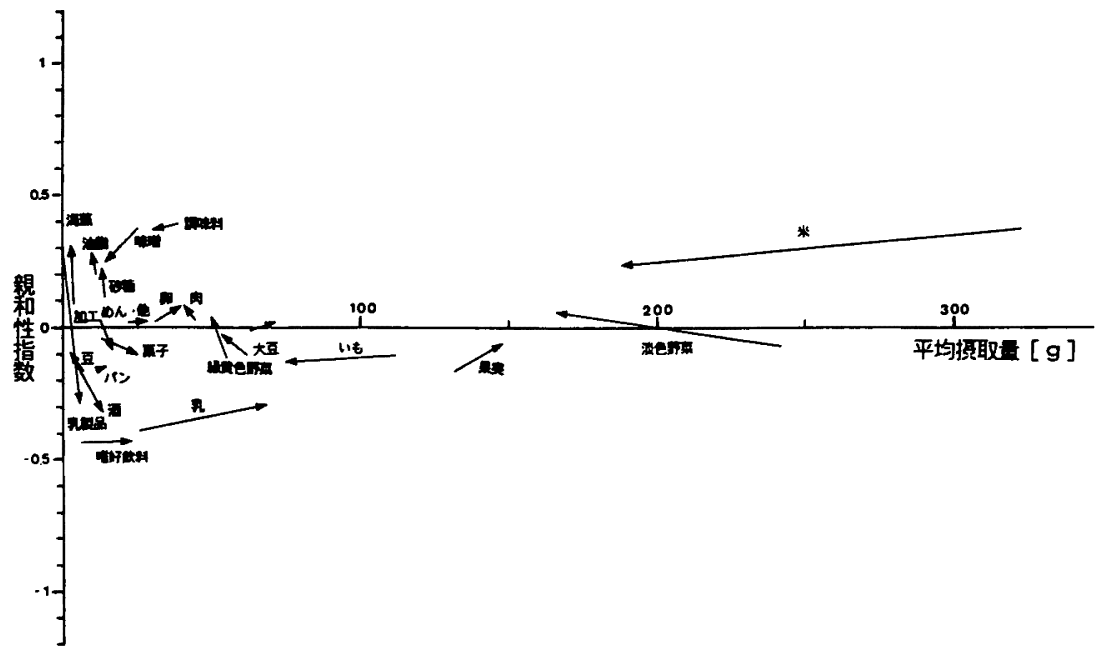

図 3-c. 平均摄取量と親和性指数（1979 年と 1989 年, 板取村）

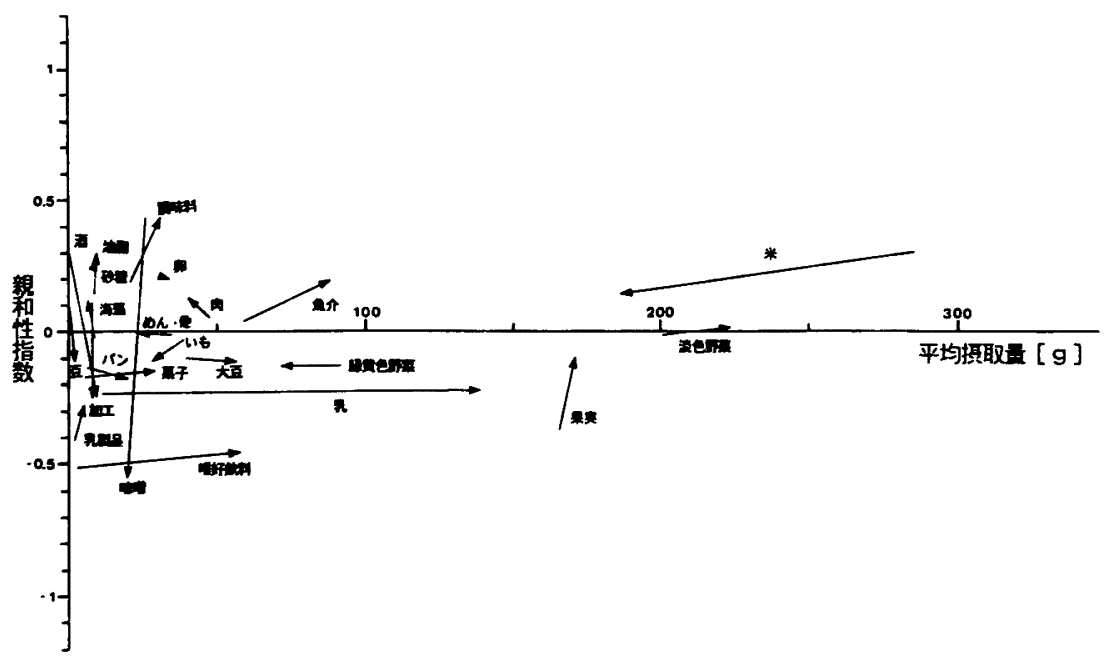

図 3-d. 平均摄取息と親和性指数（1979 年と 1989 年, 安心院町）

が上方に向かうことは，親和性が強化し，下方に向かう ことは, 親和性が弱化することを表示しており, 右方向 に移動することは摄取量の増加を, 左方向への移㲜は掫 取量の減少を表示している。大網（図 3-a）の場合，米は 左方向に大きく移功しているが(つまり摄取量は減少し ていろが), 上下方向の変化はあまりない。つまり, 親和 性の増娍はない。このような変化は, 一部の人が極端に 摄取量減少をして平均値が減少したのではなく，笨団楼 成員全員が一様に摄取息を減らしたことを図示してい
る。なお,米の摄取量の変化だけについては図 2 の散布図 にも示されているが, 図3では地区内の事情が詳しく,か つ简明に説明されている。

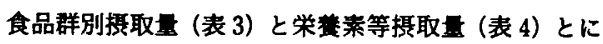
おいて，顥著な経年変化をしたことが示された板取（図 3-c), 安心院 (図 3-d), 津奈木 (図 3-e) について, こ こではその変化の内容を詳しく検討することができる。

まず,これら 3 地区ては, 米の摄取量が「左下方向」に 移功しているが,つまり, 摂取量が減少し, 親和性は弱 
まったが，まだ親和性は正領域にある。首都圈地区の大 網と中井 (図 3-b) とか「左上方向」に小幅に移動したこ とと異なった変化である。パンは中井だけが親和性が正 領域にあり,他は 4 地区とも負領域に留まっている。中井
では，パンが米・肉・卵・魚介などの常食用の食品になつ ているが，大網と三つの純猆村地区のすへてでは，間食 用の食品であって，常食用になるまでの定举はないと判 断される。また，首都圏地区と純莀村地区との相違が示

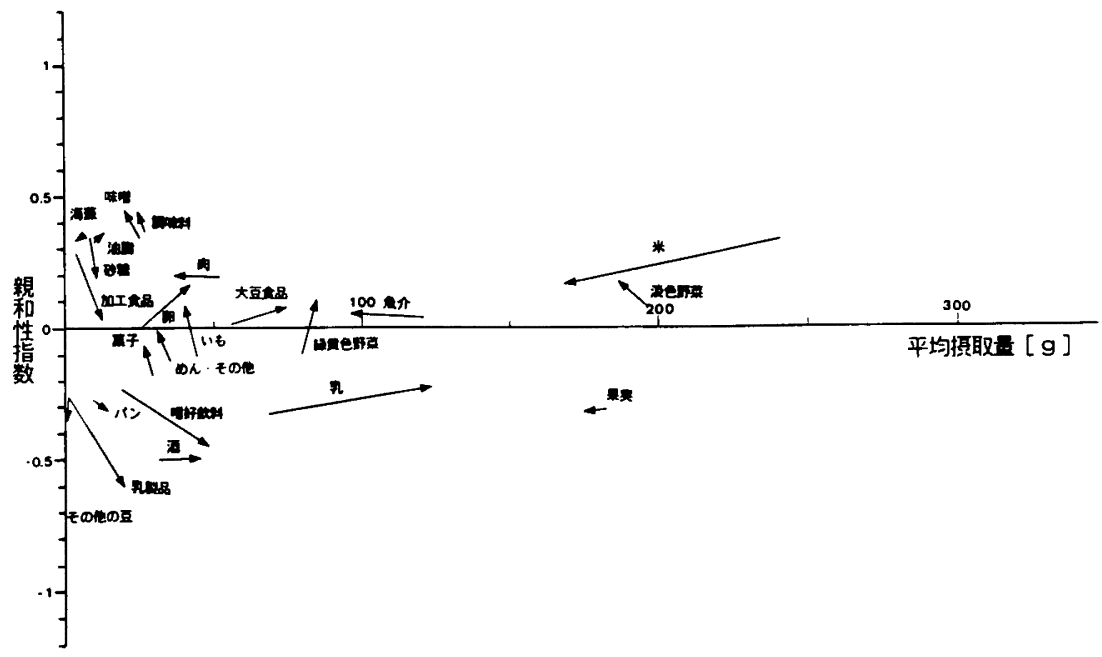

図 3-e. 平均攝取量と親和性指数（1979 年と 1989 年, 津奈木町)

表 6. 食物消霓構造の変化（1979 年と 1989 年, $N=159$ )

\begin{tabular}{|c|c|c|c|c|c|c|c|c|c|c|c|}
\hline & 米 & パン & めん & いも類 & 砂糖 & 菓子 & 油脂 & 味噌 & 大豆 & 豆類 & 果実 \\
\hline 米 & & $-0.37^{* *}$ & $-0.33^{* *}$ & $0.29 * *$ & -0.14 & -0.07 & $-0.35^{* *}$ & $0.31 * *$ & -0.07 & 0.02 & -0.04 \\
\hline パン & -0.10 & & -0.05 & -0.05 & $0.22 * *$ & $0.24^{\circ}$ & $0.45^{* *}$ & $-0.20^{\circ}$ & 0.09 & 0.07 & 0.12 \\
\hline めん・その他 & $-0.28^{* *}$ & 0.08 & & 0.03 & 0.08 & -0.10 & 0.15 & -0.07 & -0.08 & 0.06 & 0.14 \\
\hline いも類 & $0.20^{*}$ & -0.09 & $-0.16^{*}$ & & $0.24^{* *}$ & -0.07 & 0.02 & $0.22^{* *}$ & $0.22^{* *}$ & $0.16^{*}$ & -0.00 \\
\hline 砂㤑 & 0.02 & 0.08 & -0.09 & 0.08 & & $0.23^{* *}$ & $0.36^{* *}$ & 0.01 & $0.19^{\circ}$ & 0.12 & 0.13 \\
\hline 菓子 & 0.04 & -0.01 & -0.05 & 0.08 & 0.14 & & 0.07 & 0.04 & 0.01 & -0.02 & 0.11 \\
\hline 油脂 & -0.08 & $0.19^{*}$ & 0.06 & -0.02 & 0.02 & $0.22 * *$ & & -0.14 & 0.14 & 0.10 & 0.08 \\
\hline 味喑 & $0.26^{* *}$ & -0.03 & 0.01 & -0.03 & -0.02 & 0.01 & 0.03 & & 0.07 & -0.10 & -0.04 \\
\hline 大豆食品 & -0.08 & 0.04 & $0.22^{* *}$ & -0.03 & -0.02 & -0.13 & 0.14 & $0.19^{*}$ & & 0.15 & -0.02 \\
\hline その他の豆類 & -0.06 & -0.08 & -0.04 & 0.12 & $0.28 * *$ & 0.12 & -0.05 & -0.07 & -0.13 & & 0.06 \\
\hline 果実 & 0.16 & -0.01 & -0.04 & 0.02 & 0.11 & $0.24^{* *}$ & 0.11 & 0.13 & -0.03 & -0.02 & \\
\hline 緑黄色野菜 & $-0.16^{*}$ & 0.14 & $0.20^{*}$ & 0.05 & 0.04 & 0.05 & $0.32^{\circ \bullet}$ & 0.14 & $0.20^{*}$ & 0.03 & 0.06 \\
\hline 淡色野菜 & 0.04 & -0.03 & 0.05 & 0.01 & 0.01 & $0.27^{* *}$ & 0.15 & 0.07 & -0.01 & -0.02 & $0.16^{*}$ \\
\hline 海藻 & -0.01 & 0.14 & $0.19^{*}$ & -0.08 & 0.10 & 0.02 & 0.15 & 0.15 & 0.12 & 0.04 & 0.06 \\
\hline 嘼味料 & -0.07 & 0.12 & $0.24^{* *}$ & 0.11 & $0.27^{* *}$ & 0.13 & $0.16^{\circ}$ & 0.04 & $0.27^{* *}$ & 0.02 & 0.03 \\
\hline 酒類 & 0.02 & 0.13 & 0.03 & 0.00 & 0.03 & 0.00 & 0.10 & -0.03 & 0.10 & -0.07 & -0.08 \\
\hline 嗜好飲料 & 0.14 & 0.01 & 0.01 & -0.13 & -0.05 & -0.02 & -0.04 & 0.03 & 0.06 & -0.11 & -0.06 \\
\hline 魚介類 & 0.09 & -0.15 & -0.04 & 0.05 & $0.17^{*}$ & 0.12 & 0.11 & $0.21^{* *}$ & -0.03 & 0.11 & 0.15 \\
\hline 肉類 & -0.02 & 0.11 & 0.15 & 0.04 & 0.13 & $0.17^{*}$ & $0.32^{* *}$ & -0.01 & 0.09 & 0.09 & -0.04 \\
\hline 卵類 & $0.16^{*}$ & -0.01 & 0.09 & -0.02 & 0.13 & $0.23^{* *}$ & $0.23 * *$ & 0.03 & -0.10 & 0.05 & $0.28^{* *}$ \\
\hline 秏 & -0.09 & $0.17^{*}$ & 0.01 & 0.00 & -0.03 & 0.02 & 0.02 & -0.03 & 0.06 & 0.10 & -0.00 \\
\hline 乳製品 & $-0.19^{*}$ & 0.08 & 0.13 & $-0.16^{*}$ & 0.14 & 0.11 & 0.11 & -0.02 & 0.04 & -0.07 & 0.13 \\
\hline \multirow[t]{2}{*}{ 加工食品 } & -0.12 & 0.08 & 0.22 ** & 0.04 & 0.08 & 0.12 & 0.06 & -0.04 & 0.11 & 0.03 & 0.03 \\
\hline & & & & & 1 & $\begin{array}{lll}9 & 8 & 9\end{array}$ & 年 & & & & \\
\hline
\end{tabular}

$* p<0.05, * p<0.01$. 
された油脂の摄取嗑増加は首都圈地区の大網・中井とも に強い親和性を稚持したまま，わずかに減少しており， 純臀村地区は 3 地区とも親和性が増加している。油脂の 摄取量そのものが少量 (Min.は $9.5 \mathrm{~g}, \mathrm{Max}$.は $20.5 \mathrm{~g}$ )て あるので, 捸取量の增減は目立たないか，親和性の強弱 は目立って変化しており, 純鹿村地区で強くなっている ことがわかる。肉の摂取量が減っているにもかかわらず, 油脂を使った料理の普及したことが推測される。

乳については, 5 地区すべてで親和性が弱い。しかし, 中井を除く 4 地区で掞取量が大幅に増えて, かつ親和性 も增強しているのて,この 10 年の間に安定した消费状況 をするようになっていることがわかる。

また, 大網の菓子, 中井の魚介, 安心院の果実, 津奈 木の緑黄色野菜などのように,「鋭角的上昇」をしている ことは, 平均摄取量は目立って増えていないが, 地区内 の対象者達が均一の摄取量をもつようになったことを表 している。魚介 (中井), 菓子 (大網) p緑黄色野菜 (津 奈木）が同じょうな変化をしたことが示されている。ま た, 味㽞 (安心院, 板取) が減少しており, 親和性も弱 まっているのは注目に值する。このような内部事情を汲 み取ることもできるのが図 3 の長所でる。

\section{5. 食物消䨘裤造の变化}

次に 1979 年と 1989 年の食物消費構造 ${ }^{15)}$ を示した（表 6)。食品群の摄取量（g/day）に関する相関行列である。 斜線より右上半分が 1979 年の結果てあり, 左下半分が 1989 年の結果を示している。まず 1979 年における米と の関連についてみると，競合関係にあった食品群は，パ ン $(-0.37)$, めん・その他 $(-0.33)$, 砂糖 $(-0.14)$, 油脂 $(-0.35)$, 緑黄色野菜 $(-0.32)$, 酒類 $(-0.22)$, 㖺好飲料 $(-0.26)$, 肉類 $(-0.12)$, 卵 $(-0.16)$, 乳 $(-0.37)$, 乳製品 $(-0.10)$ であり, 次に補完成係にあっ た食品群はいも類 $(0.29)$, 味眳 $(0.31)$, 淡色野莱(0.14) だけであった。10 年後の 1989 年の時点では, 米に対して 競合関係にある食品群数は減少しており,パン $(-0.11)$, めん・その他 $(-0.28)$, 緑黄色野莱 $(-0.16)$, 乳 $(-0.09)$, 乳製品 $(-0.19)$, 加工食品 $(-0.12)$ である。一方, 補 完阙係の食品群数は增えており，いも類 $(0.20)$, 味咜 $(0.26)$, 果実 $(0.16)$, 嘹好飲料 $(0.14)$, 㽗 $(0.16)$ て あった。このうち㖺好飲料 $(-0.26 \rightarrow 0.14)$, 卵 $(-0.16$ $\rightarrow 0.16)$ は競合関係から補完関係に大変化したもので る。その他 10 年の間に起きた目立った変化としては, 米 が砂榶, 油脂, 酒類, 肉類に対してもっていた競合性を 解消したが，まだ補完関係を結ぶまではなっていない, 他方, 米が 1979 年には有していた補完性を 10 年後に 失った食品群は淡色野菜 $(0.12 \rightarrow 0.03)$ のみであり, こ の淡色野莱さえも相関係数が負になったわけではないの

\begin{tabular}{|c|c|c|c|c|c|c|c|c|c|c|c|c|}
\hline 緑黄色 & 淡色 & 海㩰 & 調味料 & 酒 & 㖺好 & 魚介 & 肉 & タマゴ & 乳 & 乳製品 & 加工 & \\
\hline$-0.32^{* *}$ & 0.14 & 0.03 & 0.08 & $-0.22 *$ & $-0.26^{* *}$ & -0.06 & -0.12 & $-0.16^{*}$ & $-0.37^{* *}$ & -0.10 & -0.03 & \\
\hline $0.19^{*}$ & 0.08 & 0.05 & 0.10 & 0.10 & $0.17^{*}$ & 0.04 & $0.17^{*}$ & $0.23^{* *}$ & $0.31^{* *}$ & 0.14 & 0.13 & \\
\hline 0.08 & -0.05 & -0.02 & 0.04 & -0.07 & -0.01 & -0.02 & 0.11 & 0.01 & 0.10 & -0.05 & 0.05 & \\
\hline-0.09 & $0.21^{*}$ & -0.06 & $0.33^{*}$ & -0.11 & -0.12 & -0.10 & 0.09 & 0.06 & -0.11 & -0.09 & -0.02 & \\
\hline 0.15 & $0.17^{*}$ & 0.10 & $0.27^{* *}$ & 0.11 & -0.01 & 0.10 & $0.17^{*}$ & $0.23^{* *}$ & 0.05 & $0.16^{*}$ & 0.11 & \\
\hline 0.05 & -0.01 & 0.09 & -0.13 & -0.00 & 0.14 & $0.18^{*}$ & -0.11 & $0.26^{* *}$ & 0.08 & 0.11 & $0.28^{* *}$ & \\
\hline $0.33^{* *}$ & $0.21^{\circ *}$ & 0.01 & 0.10 & 0.13 & 0.12 & 0.12 & $0.36^{* *}$ & $0.35^{* *}$ & $0.28^{*}$ & $0.30^{* *}$ & $0.18^{\circ}$ & \\
\hline-0.05 & 0.12 & -0.01 & -0.04 & -0.10 & -0.01 & -0.09 & 0.02 & 0.06 & -0.24 & 0.03 & -0.00 & \\
\hline 0.13 & 0.10 & -0.04 & $0.17^{\star}$ & -0.00 & 0.03 & 0.08 & 0.04 & 0.13 & 0.06 & 0.09 & -0.03 & 1 \\
\hline 0.02 & -0.00 & -0.05 & $0.16^{*}$ & -0.01 & -0.08 & -0.06 & 0.11 & 0.04 & 0.00 & -0.01 & -0.06 & 9 \\
\hline 0.04 & 0.11 & -0.00 & 0.01 & 0.01 & 0.03 & -0.01 & $0.21^{\circ *}$ & 0.00 & 0.12 & $0.16^{\circ}$ & -0.08 & \\
\hline & 0.12 & 0.03 & 0.03 & 0.10 & $0.31^{* *}$ & 0.08 & $0.18^{\circ}$ & $0.27^{*}$ & $0.29^{* *}$ & $0.24^{* *}$ & 0.10 & 7 \\
\hline $0.25^{* *}$ & & 0.03 & $0.28^{* *}$ & 0.00 & 0.04 & 0.00 & $0.24^{\circ *}$ & 0.07 & 0.09 & 0.05 & 0.04 & 9 \\
\hline $0.35^{\circ *}$ & $0.27^{*}$ & & -0.02 & 0.02 & 0.06 & 0.03 & 0.06 & $0.22 *$ & -0.03 & -0.06 & 0.09 & \\
\hline $0.27^{* *}$ & 0.13 & $0.23^{* *}$ & & 0.04 & 0.07 & 0.13 & 0.02 & 0.06 & -0.09 & 0.04 & 0.13 & $F$ \\
\hline-0.01 & -0.00 & -0.12 & 0.07 & & -0.04 & $0.32 * *$ & 0.13 & 0.09 & 0.07 & $0.18^{*}$ & -0.09 & \\
\hline 0.02 & 0.02 & 0.09 & -0.05 & 0.09 & & $0.22 * \bullet$ & 0.02 & $0.24^{* *}$ & $0.28^{* *}$ & 0.07 & 0.12 & \\
\hline $0.18^{*}$ & 0.15 & 0.16 & 0.11 & 0.13 & 0.11 & & -0.12 & 0.11 & $0.19^{*}$ & 0.01 & 0.10 & \\
\hline $0.23^{* *}$ & $0.27^{* *}$ & 0.10 & $0.19^{*}$ & 0.03 & -0.02 & $0.15^{\circ}$ & & $0.22^{* *}$ & 0.07 & $0.17^{*}$ & -0.11 & \\
\hline 0.05 & $0.18^{*}$ & 0.06 & 0.12 & 0.01 & $0.18^{*}$ & $0.22^{* *}$ & $0.29^{\circ}$ & 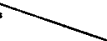 & 0.14 & $0.18^{*}$ & 0.13 & \\
\hline $0.23^{* *}$ & 0.06 & 0.10 & -0.01 & 0.04 & -0.07 & -0.00 & 0.10 & 0.04 & & 0.07 & 0.11 & \\
\hline $0.16^{*}$ & 0.02 & -0.02 & 0.04 & -0.01 & -0.02 & 0.03 & 0.02 & 0.05 & -0.03 & & 0.13 & \\
\hline $0.20^{*}$ & -0.02 & $0.27^{* \bullet}$ & $0.29 * *$ & 0.03 & -0.06 & 0.07 & -0.04 & 0.09 & 0.02 & -0.00 & & \\
\hline
\end{tabular}


である。したがって,この 10 年間に米はこれら対象者の 食生活で他の食品群に対する補完性を著しく強めたこと になる。いいかえると，米饭の攝取量が減少することと ともに, 副食品（おかず）を種々取り揄えて, 食事を橉 成するようになってきたことになる。

他方, パンが, 1979 年に競合関係にあった食品群は前 述の米 $(-0.37)$ の他には味噌 $(-0.20)$ のみであり, 補完関係にあった食品群は砂榶 $(0.22)$, 菓子 $(0.24)$, 油脂 (0.45), 大豆・大豆製品 (0.09), 果実 $(0.12)$, 緑 黄色野菜 $(0.19)$, 調味料 $(0.10)$, 酒類 $(0.10)$, 㖺好飲 料 $(0.17)$, 肉類 $(0.17)$, 卵 $(0.23)$, 秏 $(0.31)$, 秏製 品 (0.14), 加工食品 (0.13) など多数であった。また, 1989 年次でパンと親合関係の食品群は米 $(-0.37)$ の他 には, 魚介類 $(-0.15)$ のみであるが,これさえも統計 的に有意な数值ではない。一方，パンと補完関係がある 食品群は油脂 (0.19) と乳（0.17）に減少したが，その ほか統計的に有意てははなが正の相開係数が得られたの は緑黄色野菜 $(0.15)$, 調味料 $(0.16)$, 酒類 $(0.12)$, 肉 類（0.12）である。つまりパンは米との端合性は依然と して存在するが, 味捾 $(-0.20 \rightarrow-0.03)$ との競合性は 弱まり, 代わって魚介類 $(0.04 \rightarrow-0.15)$ との競合性が 強まっている。また, 砂糖 $(0.22 \rightarrow 0.08)$, 菓子 $(0.24 \rightarrow$ $-0.01)$, 豆製品 $(0.07 \rightarrow-0.08)$, 果実 $(0.12 \rightarrow-0.01)$, 畉 $(0.23 \rightarrow-0.01)$, 乳製品 $(0.14 \rightarrow 0.09)$ との補完性

表 7. 因子負荷量

\begin{tabular}{|c|c|c|c|}
\hline 食品群 & 第 1 因子 & 第 2 因子 & 第 3 因子 \\
\hline 米 & -0.5999 & 0.4330 & 0.2537 \\
\hline パン & 0.5590 & -0.0165 & 0.0150 \\
\hline めん・その他 & 0.1515 & -0.0627 & -0.2710 \\
\hline いも類 & -0.0782 & 0.6263 & -0.0586 \\
\hline 砂糖 & 0.4172 & 0.3829 & 0.0567 \\
\hline 菓子類 & 0.2643 & -0.0314 & 0.5093 \\
\hline 油脂 & 0.7101 & 0.1642 & -0.1360 \\
\hline 味噌 & -0.2098 & 0.2907 & 0.1885 \\
\hline 大豆食品 & 0.1812 & 0.2556 & -0.0012 \\
\hline その他の豆類 & 0.0818 & 0.2062 & -0.1845 \\
\hline 果実 & 0.1713 & 0.0677 & -0.1159 \\
\hline 緑黄色野菜 & 0.5023 & -0.0519 & -0.0128 \\
\hline 淡色野菜 & 0.1444 & 0.4239 & -0.0082 \\
\hline 海藻 & 0.0820 & 0.0217 & 0.1778 \\
\hline 調味料 & 0.1191 & 0.4311 & -0.0221 \\
\hline 酒 & 0.2301 & -0.0711 & -0.0449 \\
\hline 譛好飲料 & 0.3489 & -0.1511 & 0.2094 \\
\hline 魚介類 & 0.2247 & -0.0826 & 0.2471 \\
\hline 肉類 & 0.3300 & 0.2332 & -0.3194 \\
\hline 卵 & 0.4713 & 0.1483 & 0.2217 \\
\hline 乳 & 0.4627 & -0.2750 & -0.0318 \\
\hline 乳製品 & 0.3287 & 0.0659 & 0.0378 \\
\hline 加工食品 & 0.2150 & 0.0171 & 0.3440 \\
\hline
\end{tabular}

も消失または減弱していた。

\section{6. 食物消党の 2 次元空阙图（食品群）に示される 食物消霓バタンの变化}

次に, 1979 および 1989 年次の調査资料を比较するた めに, 159 人の 2 回分 (318人)の资料をひとまとめにし て，因子分析を行った。対象者（女性）の食物攝取状況 に内在するパタンおよびそれを決定している両年次に共 通の因子 ${ }^{10)}$ を得るためてある。その結果 (表 7) のうち, 第 1 ，第 2 因子を用いて食物消费の 2 次元空間 (食物) に 図示した（図 4)。同図では左上（第II象限）に米が単独 て存在しており，いも類と味噌がやや近い位置に付置し ている。他方パンは横軸右側の少し下（第IV象限）に位 专し, 粍, 乳製品, 㖺好飲料, 酒類がその付近に存在し ている。そういう配居状況から横軸（第 1 因子）は「米」 対「緑黄色野菜・油脂・卵・パン・秏をはじめとする多 数の食品群」との対比で説明でる概念であり，これを 「米」対「副食品（おかず）」の因子と読み取ることがて きる。他方，縋軸（第 2 因子）は「米・いも・味㽞・淡色 野菜・調味料・砂榶・肉等」に対する「乳・㖺好飲料 ・ 乳製品・酒・パン・めん」の対比で説明できる概念であ り, 正方向に「節理の手数がかかるもの」, 負方向に「調 理をしないまたは手数がかからないもの」が位置してい ろことから,「正式の食事」対「轻食」ないし「㬐好品偏 好」の因子と読み取ることができる。乳は親和性指数の 分析でも示したが, わが国では食卓の主要權成要素であ ろよりは，㖺好品として消費されているから，このよう に䛨み取ってもよいと考えられる。

次に,この食物消費の 2 次元空間図（地区）に各地区を 年次別にプロットし，その経年移動を図示したものが食 物消费パタンの変選（1979 年〜1989 年）(図 5) である。 この計算方法は，因子分析により得られた各個人の因子 得点を地区別・調査年次別に平均したものである。図の

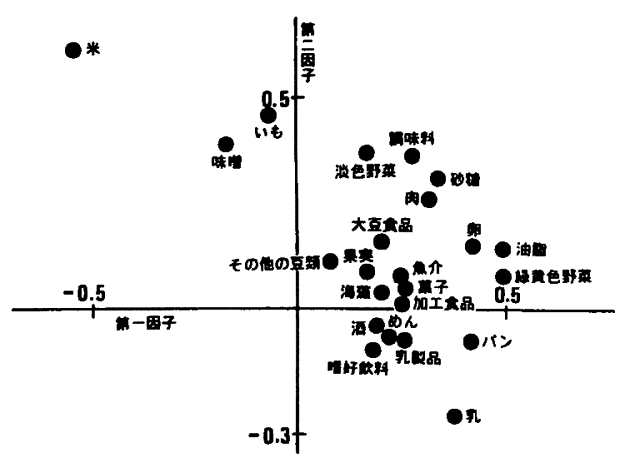

図 4. 食物消费の 2 次元空間図（食品群）(対象全体 318 名) 


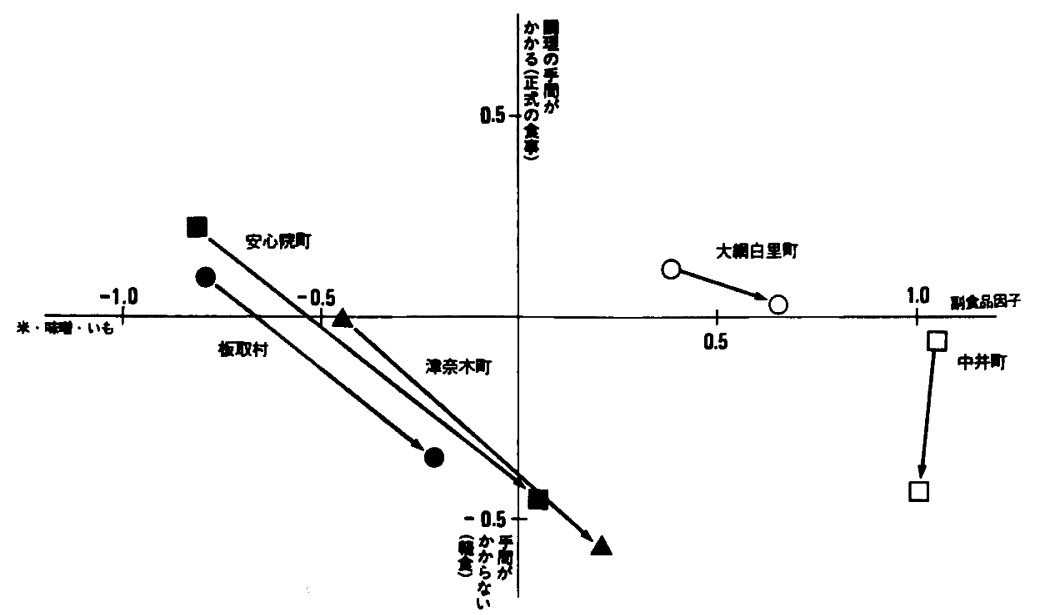

図 5. 食物消費パタンの変邉（1979 年〜1989 年）(食物消費の 2 次元空間図（人）に 2 年分をプロットしたもの）

矢印は時間的な流れ (1979 年〜1989 年) を示しており， 板取, 安心院, 津奈木の 3 地区は左上(第II象限)から右 下 (第IV象限) 人移行する傾向がある。すなわち「米飯 中心・正式食事」型加「副食品多食・赀好品偏好」型 に変わっている。しかし, 首都圈内に位㽞する大棢, 中 井の両町は, 他の 3 町村とは異貝の変化をしており, 中井 は「副食品多食型」への変化はなく,「㖺好品・柽食」型 へのみ変化している。そして大網は「副食品多食」型へ の変化が目立っている。つまり図 5 は本報告で対象とし た 5 地区の食物掫取特性を視覚的に示したことになる。 そこには純宸村部と首都圈部での食生活の変化に相连か あり,さらに首都圈部の 2 地区間にも，際だった相䢖が見 いだされた。首都圈部ては純罢村部よりも多様な変化が 起こっていることを示唆するものである。しかしそのよ うなバラエティがあっても，最終的には右下(第IV象限) に向かっており, そのことから全国的に米飯離れ, 㖺好 品（轾食, 調理をしないで食べ）の湖流が起きている ことを示唆している。

\section{7. 但差バタン類似事でみる個人・地区の变化}

次に，食物摄取量の変化を分析する方法として偏差パ タン類似率を用い, 類似と非類似とから各人と各地区の 10 年間の変化を示す。丸井ら ${ }^{1415)}$ は偏差パタン類似率を 創設したが，その諭文では多数個人間の食物攝取パタン の類似性を数量化したものであるが(1)15)，本報告の場合 には, 同一個人について 10 年間を挟んだ食物摄取パタン の変化を数量化したものである。なお，各地区ごとにそ の代表値 (平均値, 最大値, 最小値) のみを示した（表 8)。中井町では, 個人別の類似率で負の値を示した者は なく前・後 2 回の食物摄取状況はよく似ていること,つま
表 8. 10 年間を挟んだ各対象者の偏差パタン類似率

\begin{tabular}{lcrcr}
\hline \hline \multicolumn{1}{c}{ 地区 } & 人数 & 平均値 & 最大值 & 最小値 \\
\hline 大棢白里町 & 33 & 0.19 & 0.74 & -0.34 \\
中井町 & 20 & 0.56 & 0.87 & 0.13 \\
板取村 & 43 & 0.12 & 0.74 & -0.68 \\
安心院町 & 33 & -0.08 & 0.85 & -0.54 \\
津奈木町 & 30 & 0.05 & 0.66 & -0.63 \\
\hline \hline
\end{tabular}

り 10 年間に「別人になったような食べ方」をするような 変化をした人がなかったことになる。その点，板取では 最も大きく変化した者では, 偏差パタン類似率は一0.68 であり,この者では,この 10 年間でまったく異なった食 物括取パタンになったといえる（表 8)。しかし，板取は 全体として年次ごとに丸めて比べれば，0.56でありこ の 10 年間の食物摄取状況に変化が少ないことを示して いる。他方, 安心院で偏差パタン類似率 0.85 であって ほとんど変化のない者もいるが, 最も変化した者の偏差 パタン類似率が -0.54 であり,全体としてはー0.08であ ク,この地区では 10 年間に食物摂取パタンが大きく変容 したのである。また安心院ほどではないにせよ，残りの 3 地区においても摄取パタンが変容していることが示さ れた。また，各地区こととに年龄群別に食物摂取パタンの 変化を比較した場合には, 年龄群間に差は認められな かった (表 9)。したがって, 年龄棬成階層の違いによる 食物摄取状況の変化に関する諯差は小さいと判断でき る。

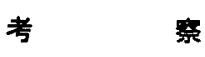

本論文では調査時点では「料理」を献立としてとらえ， 
表 9. 地区別・年龄階層別偏差パタン類似率

\begin{tabular}{lcccrr}
\hline \hline & $\begin{array}{c}\text { 大 網 } \\
\text { 白里町 }\end{array}$ & 中井町 & 板取村 & \multicolumn{1}{c}{$\begin{array}{c}\text { 安心 } \\
\text { 院町 }\end{array}$} & \multicolumn{1}{c}{$\begin{array}{r}\text { 津奈 } \\
\text { 木町 }\end{array}$} \\
\hline 50 歳末満 & 0.32 & 0.66 & 0.08 & -0.24 & 0.19 \\
50 歳代 & 0.17 & 0.49 & 0.11 & -0.08 & -0.01 \\
60 歳以上 & 0.17 & 0.54 & 0.16 & 0.04 & -0.02 \\
\hline \hline
\end{tabular}

摄取された食品を小分類の 97 食品て分類集計し、その後 に大分類の 23 「食品群」に丸めて統計処理したもので る。これまての食物提取状洗調査や栄䓹疫学などの研究 において，通常報告されてきた栄秦素等摄取状況の算定 は小分類の 97 食品て行ったが四訂・日本食品栖葓成分表 を用いた。しかし, 栄養素などの攝取状況は本研究の中 心的課題てはないのて，地区別・年次別の算出に留めた。 このようにしたのは, 本研究のねらいが, 食品群を粠成 要素とする栄蒦学の新しい理諭を權築することにあるた めでる。また，その理由は食物摄取量を用いて食物提 取状況を分析することが，実験室内の分析化学的な研究 とは異なる方法て，人間の食行動等を分析する手段とし て有奻であり, かつ, 食生活指尊, 食習慣の改善などに 有奻な手段となると考えるからてある。本論文て採り上 げた食物消费模造, 親和性指数, 偏差パタン類似率, 食 物消費の 2 次元空間図 (人・食物)などはすへてそれらの ために創り出した指数である。本論文はそれらの指数と その概念を一つの論文の中て取り揃えて, 食物提取状況
の実態を明らかにすることを意図したものである。 構成要素論（または単に「要素論」と略称することも ある）ては，構成要素（または単に「要素」ということ

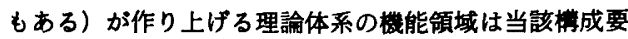
素がもつ属性によって決まることに注目している8)。本 論文ては，「大分類食品群」を笨成要素とする方法を展開 した。な扔，本論文では女性の食物提取状況資料を分析 したが，女性特有の食生活現象を解明することを意図し たものではなく，五つの地区住民の食物撖取状況を分析 したものである。したがって，とくに言明しない限り女 性特有の食生活現象を解明することに限定しない。

\section{1. 食物摄取量の变化}

個別の食品群における摄取状況の影著な変化は, まず 第一に米摄取量の娍少である(表 3)。5 地区のすべてで減 少しているが, 図6に示すごとく, 1979 年の時点で多量 に食へているほど 10 年後の減少が大である。また, 直線 回㷌を当てはめたところ, $144.9 \mathrm{~g} / \mathrm{day} て$ て減少目は 0 に なっている。この断面調查の結果を直接, 経時的変化に 当てはめることは慎重てなければならないが，米の掫取 量の減少㑯向にも底があることを示唆するものと考えら れる。他方, パンについては純㺜村地区の津奈木, 安心 院, 板取の 3 地区ては摄取量が增加していた。しかし, 首 都圈に位霬する大網, 中井の両地区ては減少しており, この 2 地区では同時に米の減少幅が小さいことと合わせ て, 純農村地区と首都圈との間に食物提取状況の変化に 変調が起こっていると考えられる(7)16)。

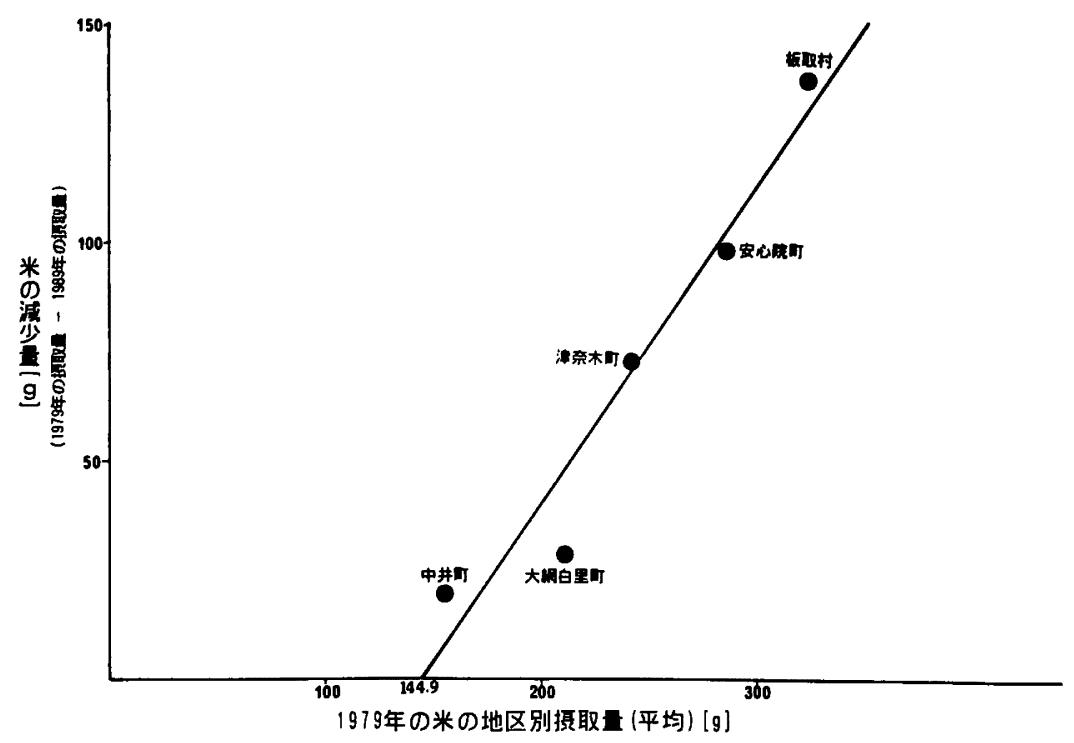

図 6. 1979 年次の米の摄取量と 10 年後の米の減少量 
表 10. 対象地区の年次推移

\begin{tabular}{|c|c|c|c|c|c|}
\hline & 大刺白里町 & 中 井 町 & 板 取 村 & 安心院町 & 津奈木町 \\
\hline \multicolumn{6}{|l|}{ 人口(人) } \\
\hline 1979 年 & 26,092 & 8,366 & 2,324 & 10,418 & 6,348 \\
\hline 1989 年 & 33,544 & 9,806 & 2,116 & 9,620 & 6,000 \\
\hline \multicolumn{6}{|c|}{ 一般歳入 (千円) } \\
\hline 1979 年 & $3,053,531$ & $1,633,806$ & $1,274,646$ & $3,546,294$ & $1,822,055$ \\
\hline 1989 年 & $7,918,547$ & $2,714,412$ & $1,696,468$ & $4,135,098$ & $2,695,686$ \\
\hline \multicolumn{6}{|c|}{ 一般歳出 (千円) } \\
\hline 1979 年 & $2,962,887$ & $1,514,529$ & $1,215,536$ & $3,491,851$ & $1,785,455$ \\
\hline 1989 年 & $7,576,944$ & $2,548.712$ & $1,556,269$ & $4,098,817$ & $2,659,121$ \\
\hline
\end{tabular}

出典は自治省財政局指恶課市町村別決算状況調。

大網と中井は, 一般葴入, 歳出や人口增減（表 10）の 状況が示すように, 人口が増え, 歳入・歳出が大幅に增 えており, 都市化ないしベッド・タウン化が進行してお り,こういうところでは食物搨取状況の変化は純榓村地 区よりも先行していると考えられる。本報告の特徽は, 婦人の個人料を分析した結果でり，上記の成樍を世 帯単位の食事調査成䋶を加工（成人換算）している国民 栄美調查等の成綡と直接的に比较することには慎重でな ければならないが, 本研究と同時期 (1979 年と 1989 年) の変化は, 次のようであった。米の摄取量は大都市では $193.1(\mathrm{~g})$ から $180.4(\mathrm{~g})$ へ, 町村では $249.6(\mathrm{~g})$ から $214.2(\mathrm{~g})$ に娍少しており，その減少幅は大都市 $12.7(\mathrm{~g})$, 町村 $35.4(\mathrm{~g})$ と, いずれも本結果よりは小さいが, 明ら かに都市部よりも農村部で大きくなっていることと符合 する ${ }^{31) 32) 。 ~}$

この他, 注目をひく結果として, 酒およひ㖺好飲料の 摂取量が全地区で増加していることである。この変化に は飲酒や㖺好飲料を掫取する習慣が女性にも徐々に普及 し始めていることたけけでなく，加朎による変化も含まれ ると考えなければならない。卵の撖取量はすべての地区 で，また乳では中井を除くすべての地区で摄取量が增加 していた。国民栄萯調査では卵の摄取量はほほ一定で経

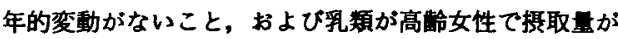

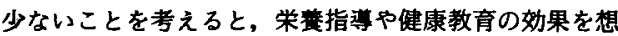
定させ，それらを交絡因子として取り报うべきだが，本 論では明確に同定することはできない。

次に, 偏差パタン類似率で類似度つまり変化の割合を 計量した成績を表 8 でみると, 中井町の全員の前後の食 物摄取状況がよく類似しており, 逆に安心院町ては類似 していない人が最多である。この状況は図 5 の状況とよ く合致している。なお，偏差パタン類似率は第 1 因子(図 4，表 7）が最も強く関連していることもわかる。

2. 食物消霓棈造からみた变化と地城差

上記の地区別・食品群別・平均摂取量で得られる情報
より，さらに詳しい情報を抽き出すために，対象集団の 食品群別攝取量について，二つの食品群間の相関係数を 計算し, 行列 (matrix) に示したものが食物消费粠造 (表

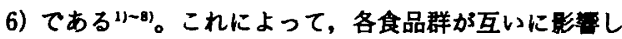
合いながら摄取されているのであって, 食品（群）間の 結びつき一食材料としての結びつき，献立における結び つきなど一を通して補完・競合の夙係が生じていること を示している。しかもこの相関行列はその結びつきを定 量的に示したものである。つまり食物摄取状況を集団レ ベルでみると, 互いに補完している食品と竸合している 食品群が存在していて, その相互関係のあり方には集団 ごとの特色があるが，それは食習娔または食文化の一つ の断面である。本報告の場合は地区格差を抜きにして, 159 名を一括して年次格差だけを示した（表 6)。この 10 年間の格差について注目すへきことは，米に対する競合 関係が消失している食品群として砂楉, 油脂, 酒類, 肉 類があり，米飯中心の食事内容が米偏重より副食品多食 に変化していることである。このうちとくに注目すべき 変化をした食品群は肉類であろう。昭和 46 年度の国民栄 䔄調查资料の分析結果では，それがわが国における最初 の食物消費推造 ${ }^{23326)}$ であるが，肉類と米とが競合してい た。しかしその後は, 肉類を使った料理が普及するにつ れて米一肉類の競合性が減少してきた。まだ米一魚介類の ように強い補完関係になってはいないが, 競合性は完全 に消失している報告例が増えている。本報告の中高年齢

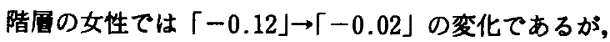
それが中高年龄女性においても認められたのである。

その他, 米と他の食品群との相関関係が競合関係より 補完関係に変化する傾向がある。たとえば緑黄色野莱 $(-0.32 \rightarrow-0.16)$, 油脂 $(-0.35 \rightarrow-0.08)$, 乳 $(-0.37$ $\rightarrow-0.09)$ などのように負の相関係数であってもその絶 対值が小さくなっている。これらのことから米飯が多種 類の食品とともに食卓にのほるようになっていることが わかる。このような食物消費粠造（表 6) は各地区ごとに 
も計算できるが，本報告ては割愛する。

3. 物摄取状況を決定する要因の分析（因子分析）

次に，上記の食物消責構造を形成する要因を明らかに したいというニードが生ずる。そのために食品群別摂取 量（g/1人 1 日）を変量として因子分析（主因子法）を行 いそれによって各地区・各年次の因子得点を算出した。 また，それによって各地域の食生活の変化を図 5 に示し た。この方法は最近，栄暴学においても，ようやく採用 され，研究報告されるようになった。多変量解析（因子 分析や主成分分析など）の手法を食物捸取量の分析に適 用することは, 複数の食品群の捸取量の增減に注目して, 総合的ないし包括的な食品群間の関係の中に要約因子を 求めることである。また, いいかえると, 個別の食品(群) の攝取量の多少・増減に留まるのではなく，個々の食品 (群) の多少・增減の椣造的把暒をするものでもある。こ

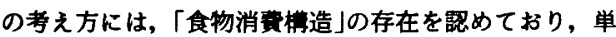
独の食品の增減や多少を超えて, 食物攝取パタンに注目 することである。

本報告ては, 各個人の因子得点の記載は省略し, 各地 区別・年次別の因子得点の変化 (図 5) として図示して検 討した。これによって，各地区は全体の中てどのような 位置一相対的な位置一にあるかが示された。このように 図 5 で説明される内容は, 平均捸取量の変化 (表 3)によ る説明を凌鴐するものであり，また「食物消費粠造」(相 関行列）（表 6）のもつ高度な情報を著しく，わかりやす く説明している。

対象とした 5 地区の両調査年次における人口と一般歳 入, 歳出を表 10 に示した。これによれば,この 10 年間に 自治体として大きく変化している地区は大網であり，人 口は $28 \%$ 増加し，自治体の年度予算としては物価上昇に よる自然増も含まれているが, 2.6 倍(160\%増加)になっ ている。他の 4 地区については，中井では人口が 17\%增 加し, 年度予算では $67 \%$ 增加している。他方, 最も変化 の小さかった地区は，安心院であり人口は $92 \% に$ 減少 し, 年度予算も $17 \%$ の增加にすぎない。また，板取，津 奈木の両地区も安心院と同様の結果である。つまり, 調 查期間において自治体として最も大きな変革をなした地 区は大網であり, 中井がそれに次いでおり, 他方変化が 小さかった地区は, 板取, 安心院, 津奈木の農山漁村地 区であった。しかし食物摄取状況については, この結果 と反対であり, 大網, 中井て変化が小さく, 他の 3 地区て 大きく変化している。このように過疎化が進行したり, 自治体として大きく変革しなかった地区の食物摄取状況 が大幅に変化したことは, 行政面の変化と食生活の変化 との間に乘離があることを示している。しかし，䈉者ら は社会的変動と食生活とが無関係ではありえないと考え るものであり, 食生活の変革または変化と人口の社会的
增減や自治体税収の增加との間に時間的ずれ (time lag) があって, 直接的に連動しないこと, およびマスメディ アの影䇾や食品流通システムでの拡充などの生活に密着 した要因の影慗が大きいことが,このような伢離の原因 と考えられる。

\section{4. 親和性指数}

親和性指数は, 個人レペルの好き・嫌いを稰人法とし て集団レペルの「㖺好」と同等に扱えないという認識に 立って考案されたものである720128)。例をあげるならば, 個人レベルての「金持ち」・「裕福」に対する「国民総生 産額 (GNP)」という尃門用語が経済学にもあるように, 地域集団や地区を取り扱う公衆衛生や公采栄蓄学の領域 でも「集団レベルの啫好」の地域特性を表す尃門用語を 作らなければならないと考えて創ったものである。

こうして求められる「標準化した親和性指数」は貿問 票調査で求められるような意識や記憶に基づく「好き・ 絮い」とは次の 2 点で異なっている。まず, 親和性指数は 摂取量から求められ，资料収集，加工，分析が客観的に 行われたものである。次いで，個人の「好き・嫌い」の 意識を質問したものではなことである。「親和性指数」 を「受容度」(acceptability) ${ }^{28)}$ と称したこともあるよう に, 当該食品が当該集団で均一に受け容れられているか, どうかを判断した指槚てある。このようにして求めた地 区別・年次別の親和性指数は表 5 に示されるが, 平均攝取 量 (地区別・年次別) と合成した図 3 が食物攝取状況の変 化を如実に示している。摄取量の隇った米は，親和性指 数が純農村地区では弱まっているが，首都圈地区では， 意外にも強まっている。米と対比されるパンの親和性指 数は 1979 年の中井を除くすべての地区・年次て負值であ り,しかも親和性を失う方向に変化していることが特徴 である。また，乳は酒類，㖺好飲料と同じ程度の親和性 を獾得しているにすぎない。いいかえると，乳が砂糖， 味噌, 油脂, 調味料のような日常の食事に必要不可欠な 存在になっていないことを示している。

\section{5. 食物捸取状況の分析法について}

本研究において，筆者らが開発した食物捸取状況調查 料の分析方法について紹介し，その「切れ味」と有用 性について検討した。今回用いた方法を整理すると，偏 差パタン類似率も親和性指数・食物消費構造・食物捸取 パタンもすへてて集団レベルの指標であるが，前者は食品 群別摂取量の平均偏差を基準として 2 者間の比較をした ものであり, 後者はすべての食品群間の相互関係, いい かえれば食品群が消费されている状況の楼造に関するも のである。このように守備範囲は同じでも，明らかにす る側面の異なる指標をどのような場面で，どのように用 いれば良いのかが問題となる。しかしこれらのすべての 指標のもとになっているのは，各対象者の食物抒取状況 
である。つまり，“食品または料理の 1 人 1 日当り摄取量” を構成要素帛として, 自分の求める結果を得るためにふ さわしい方法を選択し, 不足している部分があれば, 他 の手法て補完すればよい。

今回得られた結果ては, 都市近郊部に位羁し, 初回調 查てある 1979 年の時点において既に首都圈へのべッ ド・タウンとして機能し始めていた中井のみが，米離れ をほほ終息させていることが推測できた。他方，純然た る農村部てある板取, 安心院, 津奈木の 3 地区はこの時期 （1979１989 年）に食生活の大幅な変化がみられた。ま た, 同じ首都圈近郊でありながら, 大網の場合には中井 よりも幄れて食生活の変化が起きていた。この結果につ いては，今回用いたすへての手法において一買性が認め られ, 平均摄取量と親和性指数（図 3-a〜e）上の各地区 の動きや，食物消费パタンの変㟟 (図 5) 上の各地区の動 き,および偏差パタン類似率（表 8，9）の結果は互いに 矛盾することなく, 整合性が認められた。したがって, これらの指標や手法の有用性は支持されたと考えるもの である。

$$
\text { ま と め }
$$

食物摄取状況調査資料を用いて，計量可能な食生活実 態の分析方法を研究してきた著者らが, 独自に考萫した 親和性指数や偏差パタン類似率，および最も早い時期に 运入した食物消費構造や多変量解析などのさまさまな手 法を用いて，5 地区における 1979 年と 1989 年の 2 年次 の食物摂取状况資料の比較検討を行った。このことに よって手法の有用性を実証的に検討したものである。こ の調査期間は，米消費拡大運動（宸水省）が展開された 1977 年以後を包含しており，その期間の食物摄取状況の 変化を，辰村地区の婦人について追跡することにもなる といえる。

1）食品群別の摄取量では, 米, 味噌の摄取田が減少 し，卵，蝺の摄取量が増加していた。とくに板取村（岐 阜県), 安心院町 (大分県), 津奈木町 (熊本県) など純 農村的立地条件を備えた地区における米消費量の隇少は 著しい。しかし,これらの変化は中井町(神奈川県), 大 網白里町 (千葉県) ではほとんどみられず, 中井町の牛 乳のように, 逆方向の変化を呈している一面もある。

2）米との競合関係を示す食品が, 1979 年の時点に比 へて 1989 年では競合性を弱めたり, 逆に補完性を示す ようになったものさえあって，米飯を中心とする食事の 内容が「多様な食品で栄蓄バランスを」(健康づくりのた めの食生活指針, 昭和 60 年)にふさわしいものに変わっ ている。

3）食物消费パタンの変化については, 洋風化（近代 化）と調理の省力化があり, その変化にも純農村と首都
圈の地域性が窥えた。しかしながら，このことに対して 10 歳の加龄が交絡要因であり, 本研究では加龄要因を除 去できない。

4）筡者らが提案した食物消费構造，食物消费の 2 次 元空間図 (人または食品)，親和性指数，親和性指数と平 均の合成, 偏差パタン類似率などの手法および指標は, その目的と守備範囲はおのおの異なっているが, 整合性 のある結果を示しており，その有用性が確認された。

なお, 本研究は昭和 63 年度饭島記念食品科学振興財団 の研究助成金を受けて行った研究の一部である。

\section{文献}

1）業川裕之：化学と生物, 14，409（1976）

2) Toyokawa, H.: Proceedings: An International Workshop on the Effects of Alterations of Dietary Patterns and Food Habits on Health with Special Reference to Critical Analysis of Comparative Epidemiological Studies on Different Population (Yoshimura, H., ed.), 171 (1979), Hyogo College of Medicine (Nishinomiya)

3）罯川裕之：日本酸造協会雑誌，73，158（1978）

4）豊川裕之, 市川雅教, 松村康弘, 丸井英二, 金子 俊, 三宅由子：民族衙生, 47, 138 (1981)

5）曹川裕之, 丸井英二, 小野田博一, 村信子, 吉田節子, 金子俊, 山上雅子, 永山亩子, 赤羽正之, 西岡菜子, 石井荘子, 森口 覚: 栄蒦と食梧, 34, 531 (1981)

6) Toyokawa, H. : Dietary Influences on Cancer : Tra ditional and Modern (Schoental, R. and Connors, T.A., eds.), 37 (1981), CRC Press (Boca Raton)

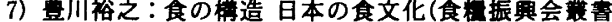
6) (1984), 全国食粠振興会 (東京)

8) Toyokawa, H.: Currents, 2 (2), 13 (1986)

9）中島風一，吉川周子：民族衙生，49，60（1983）

10）豊川裕之：栄蒦と食柦，29，71 (1976)

11）城田知子, 吉住笑美子: 日本公街誌, 37, 100 (1990)

12）丸井英二，吉田節子，基川裕之：民族街生，48，35 (1982)

13）城田知子：民族街生，57，2（1991）

14）丸井英二，曹川裕之：日本公街誌，22，385（1975）

15）丸井英二，害川裕之：日本公街誌，25，363 (1978)

16）豐川裕之：日本公舫誌, 14, 1229 (1967)

17）量川裕之：日本公街誌，15，893 (1968)

18）鼌川裕之：日本公街誌，17，15（1970）

19）蕒川裕之：日本公衛誌, 17, 367 (1970)

20）豊川裕之：日本公衡誌，17，1081（1970）

21）趼川裕之：日本公街誌，18，619（1971）

22）曾川裕之, 上住 妙:日本公衙誌，19，129（1972）

23）蕒川裕之：からだの科学，51，42 (1973)

24）害川裕之，三宅由子，伊藤雅治：日本公衛誌，22，571 (1975)

25）害川裕之：公衆街生，41，358（1977）

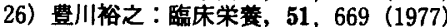

27) 蕒川裕之: Engineers, 361, 18 (1978)

28）三宅由子，䑩川裕之：日本公衛誌，22，579（1975）

29）三宅由子，豊川裕之，伊藤雅治：日本公街誌，23，689 (1976)

30）厚生省健康政策局健康增進栄責課：国民栄筇の現状 昭和 55 年度国民栄菱調査成續 (1982)

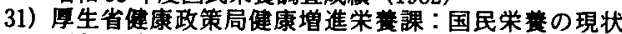
昭和 54 年国民栄装調查成綪 (1981)

32）厚生省保健医療局健康增進栄爱課：国民栄莀の現状 平成元年国民栄蓄調査成績 (1991)

(1994 年 9 月 29 日受理) 